\title{
Does sovereign creditworthiness affect bank valuations in emerging
} markets?

Williams, G.L.; Alsakka, R.; ap Gwilym, O.M.

\section{Journal of International Financial Markets, Institutions and Money}

DOI:

10.1016/j.intfin.2015.02.001

Published: 10/02/2015

Peer reviewed version

Cyswllt i'r cyhoeddiad / Link to publication

Dyfyniad o'r fersiwn a gyhoeddwyd / Citation for published version (APA):

Williams, G. L., Alsakka, R., \& ap Gwilym, O. M. (2015). Does sovereign creditworthiness affect bank valuations in emerging markets? Journal of International Financial Markets, Institutions and Money, 36, 113-129. https://doi.org/10.1016/j.intfin.2015.02.001

Hawliau Cyffredinol / General rights

Copyright and moral rights for the publications made accessible in the public portal are retained by the authors and/or other copyright owners and it is a condition of accessing publications that users recognise and abide by the legal requirements associated with these rights. study or research.

download and print one copy of any publication from the public portal for the purpose of private

- You may not further distribute the material or use it for any profit-making activity or commercial gain

- You may freely distribute the URL identifying the publication in the public portal ?

Take down policy

If you believe that this document breaches copyright please contact us providing details, and we will remove access to the work immediately and investigate your claim. 


\title{
Does sovereign creditworthiness affect bank valuations in emerging markets?
}

Gwion Williams, Rasha Alsakka* and Owain ap Gwilym

Bangor Business School, Bangor University, LL57 2DG, UK

This version: $27^{\text {th }}$ January 2015

\begin{abstract}
We analyse the impact of sovereign rating actions by S\&P, Moody's and Fitch on bank valuations in emerging markets. We find strong evidence of a rating channel for the transmission of sovereign risk to bank valuations. Collateral and guarantee channels play modest roles, but are more relevant to countries that experienced positive actions. Positive sovereign actions by S\&P have the strongest impact on bank valuations. Both negative and positive new rating information, outlook and watch actions are associated with strong market impact. The findings identify clear evidence of links between emerging market governments' external credit standing and banks' market valuation.
\end{abstract}

JEL classification: G15; G21; G24.

Keywords: Sovereign rating actions; Bank valuations; Outlook/watch signals; Rating channel; Emerging markets.

\footnotetext{
* Corresponding author. Tel.: +44 (0) 1248383571.

E-mail addresses: r.alsakka@ bangor.ac.uk (R. Alsakka),gwion.williams@bangor.ac.uk (G.Williams), owain.apgwilym@bangor.ac.uk (O. ap Gwilym).
} 


\section{Introduction}

The impact of sovereign risks on economic and financial performance has recently attracted huge attention given such serious events as the European sovereign debt crisis and the turmoil in the Middle East (e.g. Liu et al., 2013). Credit rating agencies (CRAs) are active in financial markets through disclosing credit information, which reduces information asymmetries and enables borrowers to access capital markets. Sovereign ratings are opinions of the CRAs on the ability and willingness of governments to meet their financial commitments. Sovereign ratings are particularly important in emerging economies because they are generally more risky, and the information flows are of lower quality compared to developed countries. Investors pay close attention to sovereign rating actions when investing capital in emerging countries.

CRAs' activities in emerging markets have expanded rapidly in recent years. For example, S\&P's coverage of sovereign ratings increased from seven in 1975 to 129 in December 2014, with the growth coming predominantly from emerging countries seeking access to global financial markets. Many factors motivate governments in emerging countries to seek ratings from CRAs. Sovereign ratings enhance the capability of emerging countries' governments and private sectors to access global capital markets and help to attract foreign direct investment. The net private capital flows to emerging markets reached a record volume of $\$ 1,231$ billion in 2013 (IIF, 2014). Kim and $\mathrm{Wu}$ (2008) find that improvements in an emerging market's sovereign rating improve international capital inflows in the form of foreign direct investment, international banking flows and portfolio flows. Kim and $\mathrm{Wu}$ (2011) highlight that improvements to the sovereign ratings in one region draw G7 bank inflows away from the other emerging market world regions. Using a sample of 19 emerging countries, Christopher et al. (2012) find that sovereign credit signals positively affect regional stock market integration. Rating upgrades provide benefits for surrounding countries in a 
region, while rating downgrades lead to investors shifting funds from the downgraded country into the surrounding region.

Credit risk changes are more frequent in emerging markets and events can unfold quickly and unpredictably (e.g. Russia in 2014). Thus, the role of CRAs is more challenging, problematic and costly in emerging markets. An understanding of the effects of sovereign ratings in emerging markets has become important given the significant and growing flow of institutional funds into emerging countries due to globalisation and investors' increasing focus on international diversification. Many emerging market governments have issued dollar-denominated sovereign bonds in order to give their private sectors better access to external funds. Duggar et al. (2009) identify that $71 \%$ of defaults by rated corporates in emerging markets occur during sovereign crises. They also suggest that sovereign credit risk is a key factor in corporate defaults outside sovereign credit events.

One of the main constraints for emerging market non-sovereign issuers is that their rating rarely surpasses the sovereign rating. Borensztein et al. (2013) refer to this as the sovereign ceiling 'lite', and they find that sovereign ratings can affect the cost of borrowing in the private sector. They also highlight that sovereign defaults can have a serious negative impact on the domestic economy as a whole, or have 'spillover' effects from the sovereign to private debtors. Other impacts include the imposition of direct capital controls or measures that prevent private borrowers from servicing their external obligations when the sovereign reaches a situation near default.

In general, links between sovereigns and the financial sector have become a highly topical issue. Several studies analyse potential links or contagion channels between sovereign credit risk and banks, but primarily for developed countries (see Section 2.2). Because emerging market bank ratings are strongly related to their sovereign ratings (e.g. Williams et al., 2013), actions on the sovereign rating affect banks' cost of capital, their capital 
requirements, government guarantees and to some extent their profitability from lending/borrowing decisions.

This paper investigates whether changes in sovereign creditworthiness affect the stock market valuations of banks in emerging markets. The analysis extends to consider several channels through which such effects could permeate. Effects based on the rating channel (through the sovereign ceiling), countries' levels of financial freedom, domestic credit levels, collateral and government guarantees are considered.

This paper focuses on the relative influence of actions by S\&P, Moody's and Fitch. The sample period is 2001-2011, and the data includes daily time series of sovereign rating changes along with changes to outlook and watch status. While rating changes communicate permanent changes in issuer credit quality, credit outlook and watch are supplemental instruments to signal potential rating adjustments. Prior studies show that outlook and watch actions are at least as important as rating changes in their market impact (e.g. Alsakka and ap Gwilym, 2012; Sy, 2004). We examine how the share prices of 277 banks react to sovereign rating events for 19 emerging market countries. The data allows us to identify which CRAs induce reactions in emerging market bank valuations, and which rating action type (if any) induces the strongest reactions. Prior literature shows that all three CRAs play different, but nevertheless significant roles in the markets (e.g. Afonso et al., 2012; Alsakka and ap Gwilym, 2012; Hill and Faff, 2010), yet many studies examine data from only one CRA (e.g. Caporale et al., 2012; Chen et al., 2013). We also examine the joint impact of the three CRAs by constructing a 'new rating information' variable, which can potentially demonstrate that market participants make use of the rating information provided by all three CRAs.

The key findings are as follows. There is strong evidence of a rating channel for the transmission of sovereign risk to bank valuations, while collateral and guarantee channels only play modest roles, but are more relevant to countries that experienced positive sovereign 
rating actions. We highlight unequal responses to the three CRAs' actions, driven by variations in rating policy and rating models across the three largest CRAs. Positive signals by $\mathrm{S} \& \mathrm{P}$ induce the strongest positive bank returns, while negative independent actions by Fitch are the timeliest signals. We find that both positive and negative new rating information, outlook and watch actions have a strong impact on bank valuations. We also show a stronger effect of $\mathrm{S} \& \mathrm{P}$ positive (negative) sovereign actions on bank valuations in countries with tighter (less) government controls over their banking systems. Further, Fitch actions have a stronger impact on bank valuations in countries where the financial sectors provide higher levels of domestic credit. Banks in countries with higher sovereign ratings are more affected by Moody's positive sovereign actions. Positive sovereign rating actions have a stronger (weaker) impact on bank valuations in countries running relatively lower (higher) levels of government debt. In contrast to other evidence for developed countries, we find that larger banks in emerging countries are neither perceived as being safer nor more vulnerable in times of sovereign distress.

The remainder of the paper is organised as follows. Section 2 discusses the previous literature, while Section 3 provides a framework for the empirical design. Section 4 explains the data sample and presents the methodology. Section 5 discusses the empirical results, and Section 6 concludes the paper.

\section{Literature review}

\subsection{Market impact of sovereign rating actions}

Prior literature demonstrates that sovereign rating news affects financial markets. Negative credit signals impact own-country equity and bond markets and cause significant spillovers to other countries' equity and bond markets, while upgrades have limited or insignificant impact (e.g. Kaminsky and Schmukler, 2002; Sy, 2004; Gande and Parsley,

2005; Ferreira and Gama, 2007; Hill and Faff, 2010; Afonso et al., 2012). Negative credit 
signals are typically more informative than positive ones, given the stronger negative reputational effects for a CRA being tardy in the case of downgrades.

Contrary to the findings of other studies, Ismailescu and Kazemi (2010) find that positive sovereign rating actions by $\mathrm{S} \& \mathrm{P}$ in emerging markets significantly narrow $\mathrm{CDS}$ spreads, whilst no significant effect is found around negative sovereign rating actions. Alsakka and ap Gwilym (2012) find that emerging market sovereign upgrades by S\&P are associated with significant own-country currency appreciations. They also highlight important inter-CRA differences, where Moody's has an informational lead in upgrades in developed markets, and Fitch downgrades are associated with significant currency depreciations in both developed and emerging markets. Chen et al. (2013) find that countries experience significant declines in their private investment growth following sovereign rating downgrades by S\&P. These declines following downgrades are found to last one to two years. They find that upgrades have a permanent impact on private investment growth.

\subsection{Contagion channels between sovereigns and banks}

Several studies analyse potential links or contagion channels between banks and sovereigns, but primarily for developed markets. BIS (2011) identifies four main channels through which changes in sovereign creditworthiness can affect bank funding costs and conditions, including: links between sovereign and bank ratings (ratings channel); using sovereign securities as collateral to secure funding from the central bank and market sources (collateral channel); government guarantees (guarantee channel); and banks' holdings of sovereign debt (assets holding channel).

BIS (2011) only offers brief and descriptive evidence on the rating channel. Shen et al. (2012) find that the sovereign rating commonly acts as the ceiling for domestic bank ratings. Alsakka et al. (2014) analyse the linkages between European sovereign and bank ratings, and find that sovereign rating downgrades and negative watch signals significantly 
impact bank rating downgrades during the global financial crisis. Williams et al. (2013) show that bank ratings in emerging market are particularly sensitive to sovereign rating actions, and have very high probabilities of being upgraded (downgraded) following an upgrade (downgrade) to their home sovereign. Banks' capital requirements can be tied to their credit ratings, therefore sovereign upgrades (downgrades) can lead to bank upgrades (downgrades), which subsequently can reduce (increase) a bank's cost of capital.

On the collateral channel, Correa et al. (2012) find that U.S. branches of European banks suffered a significant decline in their access to dollar funding from U.S. money market funds in 2011. They also find that the size of the decline is proportional to the increase in the sovereign risk of their home country. De Bruyckere et al. (2013) investigate the contagion effect between bank and sovereign defaults during the European sovereign debt crisis, and find that banks with potentially more volatile funding (i.e. with a higher proportion of shortterm debt in their total funding) are more exposed to shocks in the quality of their assets and exhibit higher sovereign-bank contagion, which is an indication of the collateral channel. They also find that banks with higher ratios of short-term funding along with higher sovereign debt exposures are more vulnerable to increased sovereign-bank contagion.

Another link between governments and banks is through the 'too-big-to-fail' status of some large banks, or the guarantee channel. If sovereigns find themselves in a financial distress situation, then not only their ability to explicitly or implicitly support large banks will decrease, but also market participants will be aware of this and therefore bank valuations may be affected. Alter and Schuler (2012) show that after European government intervention for distressed banks, increased sovereign default risk was found to impact on banks' CDS spreads. De Bruyckere et al. (2013) find that larger banks have lower sovereign-bank contagion since they are perceived as being too-big-to-fail. However, the default risk of larger banks is more strongly correlated with their home sovereign's default risk because 
their perceived riskiness is partly tied to the probability of government support. They also find that sovereign-bank default contagion is greater for countries running higher debt-toGDP ratios. Correa et al. (2014) find that banks which are expected to receive government support demonstrate lower stock returns after a sovereign rating downgrade, and (for their European sample of banks and sovereigns) the effect remains even after controlling for domestic government debt holdings on banks' balance sheets.

Angeloni and Wolff (2012) investigate whether banks are affected by holdings of government debt (assets holding channel), and find that banks' valuations are affected by their exposure to European sovereign debts. In particular, they show that European banks were hit by developments in Greek, Italian and Irish sovereign debts. Related to this, De Bruyckere et al. (2013) show that contagion between sovereign and bank default risk in Europe is stronger where banks' exposure to the sovereign is greater. Correa et al. (2014) report that European sovereign upgrades have a positive impact on domestic banks that hold relatively large volumes of government debt in their portfolios.

The above channels emphasise a direction of causality from the sovereign to its banks. However, the interconnections between banking and sovereign risks could induce causality in both directions. Higher banking risk transforms into higher sovereign risk because of the increased probability that a given government has to rescue the domestic banking system. The effect of banking sectors on sovereign risks depends on the quality of the financial system in terms of aggregate bank credit risk and the size and development of the banking sector within the sovereign's economy (e.g. Acharya et al., 2014, BIS, 2011). Consequently, the typical time horizon for any causal effect from banks' share values to the sovereign rating is far longer than for the reverse direction of causality. ${ }^{1}$ A deterioration of sovereign

\footnotetext{
${ }^{1}$ For example, while Lehman Brothers collapsed in 2008, the USA maintained its top-notch sovereign credit rating until 2011. Similarly, Moody's and Fitch downgraded the UK's sovereign rating in 2013, five years after the failures of the Royal Bank of Scotland and Lloyds Banking Group.
} 
creditworthiness immediately increases banks' credit risks due to the channels discussed above. BIS (2011) also highlights a key channel in the bank-to-sovereign direction, whereby there can be a drain on public resources through bank bailouts arising from the desire to maintain financial stability. ${ }^{2}$ In our emerging market sample, this scenario has very limited relevance. Further, emerging countries have generally experienced strong positive trends in their sovereign ratings over the past two decades, arising from higher oil and natural gas prices, inexpensive skilled labour and subsequent economic growth, and not typically related to developments in their banking sectors.

\section{Empirical design for contagion channels}

Several insights from Section 2.2 motivate the empirical design. First, the rating channel implies a direct link between a sovereign rating action and a bank's rating. This is expected to feed through to the bank's cost of funding and thereby its market valuation. This channel is examined using different types of sovereign credit actions (see Eq. (2) in Section 4.4, and Section 5.1). We expect banks' market valuations to increase (decline) following positive (negative) sovereign credit actions. Since we use credit actions across three CRAs, we anticipate that 'new rating information' on the sovereign will have most effect.

We also investigate how the level of government control over the banking system influences the rating channel and hence the sensitivity of banks' market valuations to recent sovereign rating actions (see Eq. (3) in Section 4.4). Beck et al. (2006) show that fewer official impediments to bank operations could stimulate efficiency and diversification that promotes stability, and thus a country with greater financial freedom is less likely to experience a banking crisis. We use the Heritage Foundation's Financial Freedom index to

\footnotetext{
${ }^{2}$ This scenario arguably had most effect in the context of European countries, particularly Ireland, Spain and the UK, during the global financial crisis. Yet, Alsakka et al. (2014) find no evidence whatsoever of a bank-tosovereign channel (only a sovereign-to-bank ratings channel) in European countries.
} 
measure a country's banking efficiency and its independence from government control and to indicate the level of government regulation of financial services, the degree of government intervention in the financial sector, and the level of financial and capital market development. Higher values indicate fewer restrictions on banking freedoms. Williams et al. (2013) show that the lower the country's financial freedom score (stronger government control), the more likely are bank ratings of emerging countries to follow recent sovereign rating upgrades. Hence, for countries which experience positive sovereign rating actions, we expect the positive effect on bank valuation to be stronger in countries with tighter controls over their banking systems. Williams et al. (2013) also show that banks in countries with less government control are more likely to be downgraded following sovereign rating downgrades. Hence, for countries which experience negative rating actions, we expect the negative effect on bank valuation to be stronger in countries with less government control over their banking systems. Further, we control for a country's banking sector depth and financial sector development using domestic credit/GDP (obtained from the World Bank). We expect sovereign rating actions to have a larger impact on bank valuations in countries with higher values of domestic credit/GDP, since a sovereign rating change is likely to have a strong economic impact in such cases.

Second, we use rating levels to investigate the presence of a collateral channel. Fig.1 illustrates that low and intermediate sovereign ratings dominate our data sample (with very few rating observations above the 'A' category). It is well established since Diamond (1991) that lower-rated debt issuers will be more heavily dependent on short-term funding and may have no access to medium- or long-term funding. Alongside the sovereign ceiling effect, whereby bank ratings, particularly in emerging markets, rarely surpass the sovereign rating (e.g. Shen et al., 2012; Williams et al., 2013), we infer that any effect via the collateral channel will be most apparent in countries with lower sovereign ratings. Therefore, the 
collateral channel may induce a stronger effect of negative (positive) rating actions on banks in emerging markets with relatively low (high) sovereign ratings, because they will be more (less) dependent on short-term funding. Hence, this channel is studied via the comprehensive credit rating level of a given country (see Eq. (2) in Section 4.4). ${ }^{3}$

Third, following De Bruyckere et al. (2013) and Correa et al. (2014), the guarantee channel is studied via the debt-to-GDP ratio and the size of banks' total assets (see Eq. (4) in Section 4.4). We test whether larger banks are perceived as being safer since they can benefit from government support. Alternatively, in times of sovereign distress, larger banks may become more vulnerable since the probability of the home government being able to support the large banks decreases. The debt-to-GDP ratio enables the investigation of how market participants perceive a government's ability to support its banking sector. A government with relatively high indebtedness may be perceived as being less able to support its banking sector during times of stress, which could be reflected in bank stock prices' reactions to sovereign credit actions.

Finally, detailed bank-level data on domestic government debt holdings are sparse, and therefore we are unable to examine the assets holding channel. As part of the 2011 bank stress tests, the European Banking Authority published bank-level data on government debt holdings as of year-end 2010 for banks in 21 European countries (used by prior studies, e.g. Angeloni and Wolff, 2012; De Bruyckere et al., 2013; Correa et al.; 2014). Unfortunately, there is no similar test for banks in emerging countries that would offer suitable data.

\footnotetext{
${ }^{3}$ Rating channel variables and the comprehensive credit rating level of a given country (see Table 1) are also retained in Eq. (3) and Eq. (4).
} 


\section{Data and methodology}

\subsection{Sample selection}

The initial sampling is based on countries' GNI per capita in the 2011 World Bank country classification. All low-income and middle-income countries are defined as being 'emerging'. The emerging market bank shares must be listed and traded in order to be selected. Using DataStream, the share prices are gathered for all the listed banks from countries that meet the emerging market criteria and have share prices available from January 2000 onwards. The final sample consists of 19 emerging market countries. ${ }^{4}$

Data is available for a total of 277 qualifying banks from these countries. 160 of the banks are rated by at least one of S\&P, Moody's and Fitch. ${ }^{5}$ The bank data is unbalanced by country, since the numbers of listed banks vary across countries, e.g. there are eight Argentinean banks and fourteen Chinese banks which meet the selection criteria. The bank data is also unbalanced by time in some cases, because there can be more banks in the sample for a country in a certain year than for the same country in another year, which arises due to new stock market listings or bank mergers and acquisitions.

The sample only includes financial institutions because there is a far stronger link between sovereigns and banks than corporations (see Borensztein et al., 2013; Huang and Shen, 2014). For example, corporates do not use sovereign bonds as collateral and for this reason are not equally affected by sovereign rating fluctuations. In addition, the guarantee channel is only applicable for banks and not corporates, since banks receive government support (e.g. deposit insurance schemes, lender of last resort), and (too-big-to-fail) banks tend

\footnotetext{
${ }^{4}$ Sample construction is driven by banks' listed status and available bank share price data, not by selection of countries. The countries in the sample are as follows: Argentina, Brazil, Bulgaria, Chile, China, Colombia, Egypt, India, Indonesia, Malaysia, Mexico, Pakistan, Philippines, Poland, Romania, Russia, South Africa, Thailand, and Turkey.

${ }^{5}$ Empirical testing controlled for rated versus non-rated banks, but no significant effect was identified (results are available upon request).
} 
to be rescued by governments during financial distress periods. Further, banks are typically more likely than corporations to be rated at the sovereign ceiling (e.g. Huang and Shen, 2014). Borensztein et al. (2013) find that the links between corporate and sovereign risks are more significant in countries where capital account restrictions are in place and in countries with high political risk.

\subsection{Credit rating data}

The credit dataset includes daily long-term foreign-currency sovereign ratings, outlooks and watch status by S\&P, Moody's and Fitch from $1^{\text {st }}$ January 2001 to $30^{\text {th }}$ September 2011. All actions are verified by using S\&P, Moody's and Fitch publications. Positive credit actions include rating upgrades, positive outlook signals, positive watch events, and a combination of these i.e. a sovereign can be upgraded and simultaneously placed on positive outlook or positive watch. Negative credit actions include rating downgrades, negative outlook signals, negative watch events, and a combination of these i.e. a sovereign can be downgraded and simultaneously placed on negative outlook or watch. ${ }^{6}$

Rating upgrades (downgrades) are defined as an upward (downward) move in the 20notch numerical scale $(\mathrm{AAA} / \mathrm{Aaa}=20, \mathrm{AA}+/ \mathrm{Aa} 1=19, \mathrm{AA} / \mathrm{Aa} 2=18 \ldots \mathrm{Caa} / \mathrm{CCC}-=2$, $\mathrm{Ca} / \mathrm{CC} / \mathrm{C} / \mathrm{SD}-\mathrm{D}=1) .{ }^{7}$ Table 1 illustrates the 20 -notch scale in full. Negative watch actions include placing sovereign $j$ on watch for possible downgrade, and the action of confirming the rating of sovereign $j$ after being on watch for possible upgrade. Positive watch actions include placing sovereign $j$ on watch for possible upgrade, and the action of confirming the rating of sovereign $j$ after being on watch for possible downgrade. Negative outlook actions include changes to negative outlook from stable/positive outlook, and changes to stable

\footnotetext{
${ }^{6}$ Upgrades (downgrades) are never combined with opposing outlook or watch actions, e.g. an upgrade is not combined with a negative outlook or watch action.

${ }^{7}$ Multiple-notch sovereign rating upgrades (downgrades) are rare in this sample, therefore we focus on rating upgrades (downgrades) as one group.
} 
outlook from positive outlook. Positive outlook actions include changes to positive outlook from stable/negative outlook, and changes to stable outlook from negative outlook.

Table 2 presents summary data on the S\&P and Moody's (Fitch) sovereign credit actions for 19 (18) emerging market countries. There are a total of: 154, 122 and 128 sovereign rating actions for S\&P, Moody's and Fitch, respectively. ${ }^{8}$ There are $47(21), 43$ (9) and 38 (19) upgrades (downgrades) by S\&P, Moody's and Fitch, respectively. Most of the upgrades and downgrades are by one-notch, however, there are four, six and five cases of multiple-notch rating changes for S\&P, Moody's and Fitch, respectively. Some of these upgrade and downgrade actions are combined with either a positive (negative) outlook adjustment, or a negative watch adjustment. There are 21,10 and 13 rating changes by $S \& P$, Moody's and Fitch, respectively, announced simultaneously with an outlook/watch action (see Rows 11 - 14 in Table 2).

The dataset also comprises: 49 (31), 32 (11) and 40 (23) positive (negative) outlook adjustments that are announced in isolation, i.e. with no simultaneous upgrade (downgrade), by S\&P, Moody's and Fitch, respectively; and 2 (4), 25 (2) and 4 (4) positive (negative) isolated watch announcements by S\&P, Moody's and Fitch, respectively. ${ }^{9}$ The proportion of positive (negative) rating actions as a percentage of the total rating actions by S\&P, Moody's and Fitch is 64\% (36\%), 82\% (18\%) and 64\% (36\%), respectively, (see Rows $15-17$ in Table 2). This reflects the strong upgrade trend in emerging markets during this time period.

\footnotetext{
${ }^{8}$ In total, there are 182, 147 and 149 sovereign rating actions by S\&P, Moody's and Fitch for these countries in this time period. However, there is insufficient bank share price data for Bulgaria, Romania and Russia pre-May 2006, June 2004 and December 2004, respectively. Another reason for the loss of credit data is the new presidency and capital crisis in Pakistan in 2008, where trading of shares was affected from mid-September 2008 to mid-December 2008, therefore the observations are restricted to before this time period. Also, the 2011 Egyptian revolution affected trading of bank shares from 28th January 2011 to 23rd March 2011. Therefore, rating actions to Egypt during and after this time are omitted.

9 The two positive watch actions by S\&P in the sample are occasions where a sovereign rating was taken off negative watch to stable outlook with no rating change. Under the definition in this section, this is regarded as a positive watch action.
} 
$\mathrm{S} \& \mathrm{P}$ is the most active amongst the three CRAs with 154 total sovereign rating actions (98 positive and 56 negative actions) compared to 122 (100 positive and 22 negative) and 128 ( 82 positive and 46 negative) from Moody's and Fitch, respectively. S\&P is also the CRA with rating actions most likely to present new sovereign rating information to the market. We define a sovereign rating action that presents 'new rating information' to be a rating action to sovereign $j$ which is either in the opposite direction to the previous rating action (i.e. a positive action following a negative action) it received by any of the three CRAs, or a rating action that takes sovereign $j$ to a new rating level, either below the prevailing lowest rating by the other two CRAs or above the prevailing highest rating by the other two CRAs according to the 58-point numerical scale. ${ }^{10}$ Under this definition, $54 \%$ of S\&P's sovereign rating actions present new rating information compared to $46 \%$ by Moody's and 39\% by Fitch (see Rows 22 - 24 in Table 2).

An important point to consider is the clustering of sovereign rating actions, which is of particular importance in crisis periods e.g. Argentina faced five negative rating actions from the three largest CRAs between $19^{\text {th }}$ March 2001 and $28^{\text {th }}$ March 2001. There are six cases in the credit sample where a sovereign rating receives actions by two CRAs on the same day, namely Argentina by Moody's and Fitch on $28^{\text {th }}$ March 2001 and $12^{\text {th }}$ October 2001, Brazil by Moody's and Fitch on $26^{\text {th }}$ June 2002, the Philippines by S\&P and Fitch on $11^{\text {th }}$ July 2005, and Thailand by S\&P and Fitch on $19^{\text {th }}$ September 2006 and $1^{\text {st }}$ December 2008. For each case, the sovereign ratings received negative actions by both CRAs involved. To account for the clustering of sovereign rating actions, we define an event for sovereign $j$ as being 'clustered' when it has received another rating action within 21 trading days (of day

\footnotetext{
${ }^{10}$ For the latter 'new rating information' criteria, we use a 58-point comprehensive credit ratings (CCR) scale, which includes actual ratings as well as outlooks and watch, as follows: $\mathrm{AAA} / \mathrm{Aaa}=58, \mathrm{AA}+\mathrm{Aa} 1=55$, $\mathrm{AA} / \mathrm{Aa} 2=52 \ldots \mathrm{CCC}-/ \mathrm{Caa} 3=4, \mathrm{CC} / \mathrm{Ca}, \mathrm{SD}-\mathrm{D} / \mathrm{C}=1$, and we add ' +2 ' for negative watch, ' +1 ' for positive outlook, ' -1 ' for negative outlook, ' -2 ' for negative watch, and ' 0 ' for stable outlook and no watch/outlook assignment. Table 1 presents the full 20-notch and 58-point CCR scales.
} 
$\mathrm{t}=0$ ) by any of the three CRAs. We also define an 'independent' event, when sovereign $j$ experiences a rating action without having received another rating action in the same $(-10$, +11) window. The sample is split into independent and clustered actions for both positive and negative events. From Table 2, negative events are more likely to be clustered, i.e. 39\% (22/56), 55\% (12/22), and 37\% (17/46) of the total negative events from S\&P, Moody's and Fitch, respectively, are clustered, whereas 21\% (21/98), 24\% (24/100), and 26\% (22/82) of the total positive events are clustered.

\subsection{Abnormal returns}

We employ event day methodology to examine the reaction of bank share prices to their home country's sovereign rating actions. The share prices are quoted in their local currencies and are transformed into log returns. We carefully consider an appropriate method to calculate the abnormal returns. Holthausen and Leftwich (1986) argue that the results over short time windows immediately around the event date are not sensitive to different measures of abnormal returns. Hill and Faff (2010) prefer the mean-adjusted returns to calculate the abnormal returns, and they also use a market model and index model for robustness, and their findings do not change. Therefore, we select the mean-adjusted returns method to calculate the abnormal returns. The mean daily return for each bank prior to a sovereign rating event is calculated using 200 daily observations for the period $t=-230$ to $t=-30$, where $t=0$ is the event day (i.e. a sovereign rating action). ${ }^{11}$ This represents the expected daily return (ER). Daily abnormal returns (AR) are calculated for each day in the event window as follows:

$$
A R_{i t}=R_{i t}-E R_{i t}
$$

Where: $i=1,277$ (banks);

$A R_{i t}=$ abnormal log return of bank $i$ at time $t$.

\footnotetext{
${ }^{11}$ In the event of market closures e.g. national holidays, the time period is extended as necessary.
} 
$R_{i t}=\log$ return of bank $i$ at time $t$.

$E R_{i t}=$ expected log return of bank $i$ at time $t$.

Cumulative abnormal returns (CARs) are evaluated over the pre-event $(-10,-1)$, event $(0,+1)$ and the post-event $(+2,+11)$ windows. Gande and Parsley (2005) suggest the short two-day $(0,+1)$ event window to reduce contamination from other credit events. The preevent $(-10,-1)$ window will capture market sentiment immediately before the event, and the post-event $(+2,+11)$ window will capture any delayed market impact from the sovereign credit events. Standard errors are calculated following Boehmer et al.'s (1991) standardized cross-sectional test, to account for event induced variance. ${ }^{12}$

\subsection{Panel data estimations}

We conduct panel data estimations with country and time fixed effects to investigate the factors that affect the CARs of banks around the time of sovereign rating actions. ${ }^{13}$ Following recent literature, separate panel estimations are run for positive and negative sovereign rating actions (Gande and Parsley, 2005; Ferreira and Gama, 2007; Afonso et al., 2012). All panel estimations are run for an aggregate index of sovereign rating actions by all three CRAs to examine market participants' perceptions of the sovereign credit rating information available to them from the three CRAs. We also perform panel estimations for each CRA individually to highlight which CRA's actions may be driving the results.

\footnotetext{
${ }^{12}$ The MSCI All Countries World Index is utilised to calculate the standardized residual. We test whether the results are being affected by thin trading using a sub-sample filtered according to the amount of non-zero returns in the 200-day estimation period $(t=-230$ to $t=-30)$. If there are fewer than 100 daily returns available in an estimation period then the observation is excluded (see Holthausen and Leftwich, 1986). In the interests of brevity, we do not report these results, but we can confirm that accounting for thin trading makes no difference to the conclusions drawn. These results are available upon request.

13 We perform Hausman tests in all panel estimations to determine whether fixed or random effects specifications are most appropriate. The Hausman test results support the use of fixed effects.
} 
The first set of panel data estimations tests the sovereign rating channel and collateral channel variables (see Section 3), as follows:

$C A R_{i j t}=\alpha+\beta_{1}$ New rating information ${ }_{j t}+\beta_{2}$ Speculative to investment $_{j t}+\beta_{3}$ Investment to speculative $_{j t}$ $+\beta_{4}$ Out/watch $_{j t}+\beta_{5}$ Combined $_{j t}+\beta_{6} C C R_{j t}+\beta_{7}$ Pspillover $_{j t}+\beta_{8}$ Nspillover $_{j t}+\beta_{9}$ Plagged $_{j t}$ $+\beta_{10}$ Nlagged $_{j t}+\gamma \mathrm{Co}_{j t}+\varsigma Y_{j t}+\varepsilon_{i t}$

$C A R_{i j t}$ is the mean-adjusted cumulative abnormal return of bank $i$ domiciled in sovereign $j$ in the two-day event window $(0,+1)$ around a sovereign rating action at time $t$. The following variables are used to examine the sovereign rating channel. New rating information is a dummy variable that takes the value of one if the sovereign rating action satisfies the new rating information criteria defined in Section 4.2, and zero otherwise. Speculative to investment (Investment to speculative) is a dummy variable that takes the value of one if the rating action takes event sovereign $j$ from speculative (investment) grade to investment (speculative) grade, and zero otherwise. This variable captures whether this threshold is important in this context. Out/watch is a dummy variable that takes the value of one if the sovereign rating action is a change to the outlook or watch status only (with no actual rating change), and zero otherwise. Combined is a dummy variable that takes the value of one if sovereign $j$ has experienced multiple events on date $t$ by either the same CRA (i.e. sovereign $j$ is upgraded (downgraded) and simultaneously placed on positive (negative) outlook or watch by the same CRA) or by more than one CRA on date $t$ (i.e. for the aggregate case), and zero otherwise. Sovereign rating upgrades (downgrades) that occur in isolation (i.e. with no simultaneous placement on outlook or watch) are taken as the reference category in order to examine whether certain types of rating actions induce a stronger (or weaker) reaction in the bank share prices.

$C C R$ is the comprehensive credit rating level of country $j$ (see Table 1). We use $C C R$ to examine the collateral channel (see Section 3). We control for potential cross country 
spillover effects from non-event country rating actions to the bank share prices with Pspillover (Nspillover). ${ }^{14}$ Pspillover (Nspillover) is a positive (negative) net total rating change according to the logit-type transformation of the 58-point rating scale (LCCR $)^{15}$ by all three CRAs to sovereigns in the same world region as sovereign $j$ in the 10 trading days prior to event date $t$. This variable does not include any rating change that may have occurred to sovereign $j$ during the same time period. Pspillover (Nspillover) controls for the sovereign rating trend of countries in the same world region as sovereign $j$ according to the World Bank's region definitions. ${ }^{16}$ Following Ferreira and Gama (2007) and Ismailescu and Kazemi (2011), we control for the intensity of sovereign j's past events with Plagged (Nlagged). Plagged (Nlagged) is the positive (negative) net total rating change according to the logittype transformation of the 58-point rating scale (see footnote 15 and Table 1) to sovereign $j$ by all three CRAs in the 10 trading days prior to event date $t$. The absolute values of Nspillover and Nlagged are used for ease of interpretation. Co and $Y$ are full sets of country and year dummies to control for the country and time fixed effects. This rules out purely cross-country explanations and any overall time trend.

The methodology employed is similar to Gande and Parsley (2005) in considering event days only. This is a crucial point to recall when interpreting the results in the following section. In order to obtain robust estimators to any potential heteroscedasticity and/or autocorrelation in the residuals, a White correction is performed on the standard deviation of the estimated coefficients (Gande and Parsley, 2005; Ferreira and Gama, 2007).

\footnotetext{
${ }^{14}$ See Section 2.1, where we discuss literature on cross-country spillover effects of sovereign rating actions.

${ }^{15}$ The logit-type transformation of the 58-point rating scale (LCCR) addresses possible non-linearity in the rating scale, whereby LCCR $=\ln [$ CCR/ (59-CCR)]. See Sy (2004) and Table 1.

${ }^{16}$ We have merged the following into two regions: (i) Africa merged with Middle East and North Africa; (ii) South Asia merged with East Asia and Pacific.
} 
The next set of panel estimations examines whether the impact of sovereign rating actions on bank valuations is influenced by the government control over the banking system and the level of domestic credit (see Section 3). The model is as follows:

$C A R_{i j t}=\alpha+\beta_{1}$ New rating information ${ }_{j t}+\beta_{2}$ Speculative to investment $_{j t}+\beta_{3}$ Investment to speculative $_{j t}$

$+\beta_{4}$ Out/watch $_{j t}+\beta_{5}$ Combined $_{j t}+\beta_{6} C C R_{j t}+\beta_{7}$ Pspillover $_{j t}+\beta_{8}$ Nspillover $_{j t}+\beta_{9}$ Plagged $_{j t}$

$+\beta_{10}$ Nlagged $_{j t}+\beta_{11}$ Financial freedom ${ }_{j t}+\beta_{12}$ Domestic credit/GDP ${ }_{j t}+\gamma C o_{j t}+\varsigma Y_{j t}+\varepsilon_{i t}$

The financial freedom index (obtained from the Heritage Foundation) ranks a country from 0 to 100, in intervals of 10 (see Beck et al., 2006; Williams et al., 2013). The financial freedom of our sample countries varies from 30 to 70 inclusive. Scores of 30 and 40 represent countries with extensive and strong government interference, respectively. Scores of 50 and 60 represent countries with considerable and significant government interference, respectively. The group of countries with the highest value of 70 in the sample represents countries with limited government interference. Domestic credit/GDP (obtained from the World Bank) is the domestic credit provided by the financial sector as a share of GDP, which controls for a country's banking sector depth and development.

The final set of panel estimations utilises a set of variables that aims to examine the guarantee channel (see Section 3). The model is as follows:

$C A R_{i j t}=\alpha+\beta_{1}$ New rating information ${ }_{j t}+\beta_{2}$ Speculative to investment $_{j t}+\beta_{3}$ Investment to speculative $_{j t}$

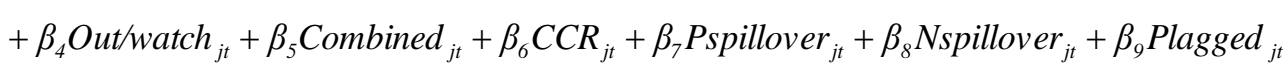

$+\beta_{10}$ Nlagged $_{j t}+\beta_{11}{\text { Debt } / G D P_{j t}+\beta_{12} T A / G D P_{i j t}+\gamma C o_{j t}+\varsigma Y_{j t}+\varepsilon_{i t}}$

Debt/GDP is the total government debt as a percentage of GDP of the emerging sovereign $j$ from the previous year to the sovereign rating action. $T A / G D P$ is the total assets of bank $i$ relative to the size of the domestic economy of sovereign $j$. 


\section{Empirical results and discussion}

\subsection{Preliminary analysis}

Panel A of Table 3 presents the average bank mean-adjusted CARs around positive sovereign credit events, while Panel B of Table 3 presents the average bank mean-adjusted CARs around negative events.

\subsubsection{Positive credit events}

Positive rating actions by $\mathrm{S} \& \mathrm{P}$ are associated with positive and significant CARs of $1.78 \%$ in the pre-event window and $0.91 \%$ in event window. All sub-samples for S\&P present consistent event-window results and the strongest event window CARs appear in the combined actions and new rating information sub-samples, at $1.77 \%$ and $1.72 \%$ respectively. The post-event average CAR for outlook and watch actions is positive and significant, implying a persisting effect.

For Moody's, the results for all types of positive actions are unexpected because negative and significant CARs are found in the pre-event and event windows. However, new rating information actions by Moody's are associated with a positive CAR of $0.29 \%$ in the event window, but it's insignificant. The significant post-event window CAR of $0.81 \%$ surrounding outlook and watch actions and $0.76 \%$ for clustered events, suggests that these types of events have a delayed positive relation with the bank share prices.

New rating information and combined actions by Fitch have positive CARs in the event window, however both are insignificant. The event window average CAR is negative and significant in the all actions, outlook and watch signals, independent, and clustered samples. We observe positive and significant CARs in the pre- and post-event windows for combined actions, which suggest that these types of actions occur when market sentiment is already positive due to other good news in the market. 
The observation of negative responses to some types of positive rating news by Moody's and Fitch deserves some further rationalisation. In what ways could positive news for the sovereign imply negative news for banks? There are several possibilities, including (i) greater corporate access to international fund flows (as in Kim and Wu, 2008, 2011) hence less role for local banks; (ii) expectation of declining margins on lending as future interest rates fall; (iii) greater government confidence in its economic policies, which could have implications for taxation and regulation of the financial sector; (iv) a very inefficient stock market. However, the effects are investigated further in the multivariate analysis.

\subsubsection{Negative credit events}

For $\mathrm{S} \& \mathrm{P}$, a significant average $\mathrm{CAR}$ of $-4.67 \%$ in the pre-event window and an insignificant event window CAR are reported for 'all actions'. This suggests that S\&P negative events are either following bad news already known in the market or that they are anticipated. The positive and significant post-event window CAR of $1.68 \%$ suggests that the market is anticipating S\&P negative actions. Negative outlook and watch signals and clustered actions are informative, with event window CARs of $-1.10 \%$ and $-1.69 \%$.

Almost all types of negative credit actions by Moody's have significant relations with bank valuations, given the negative and significant event window CARs. Moody's combined actions, outlook and watch signals, new rating information actions and clustered actions have significant pre-event window CARs, suggesting that these actions happen either during times of negative market sentiment due to other adverse news that exists, or that the markets are anticipating an impending sovereign rating action, or both. Yet, the insignificant post-event CARs suggest that the bank share prices are correlated with the rating actions, because if they are reacting to some other adverse news, then one would expect negative and significant postevent CARs. The bank share prices are linked to actual rating downgrades because 
insignificant pre- and post-event window CARs surround the significant and negative event window CAR of $-1.47 \%$.

Negative actions by Fitch are negatively and significantly related to the banks' share prices, with an overall event window average CAR of $-0.78 \%$. The insignificant pre- and post-event window CARs suggest that there is a relationship between negative sovereign credit actions and bank share prices, and that it is not other news affecting the banks. This result seems to be driven by the negative outlook and watch signals because we observe a significant event window CAR of $-1.33 \%$. Independent actions show clear-cut results with a significant event window CAR of $-0.47 \%$, and insignificant pre- and post-event window CARs. There is also a significant relation with clustered actions, with pre-event and event window CARs of $-5.52 \%$ and $-1.35 \%$.

\subsection{Sovereign rating and collateral channels}

Table 4 presents the results from estimations based on Eq. (2). Panel A considers positive sovereign rating actions, whereby positive (negative) coefficients indicate stronger (weaker) impacts on bank valuations compared to upgrades as the reference case. We find that new rating information actions by S\&P and Fitch (not Moody's) significantly increase the twoday CARs of banks by $0.69 \%$ and $1.13 \%$, respectively. Increased abnormal returns of $3.69 \%$ (7.12\%) are found within one day following positive rating actions that take the sovereign from speculative to investment grade by S\&P (Fitch). Positive outlook and watch actions and combined actions by Fitch have a significantly weaker impact on bank valuations than do actual upgrades (with no outlook/watch adjustment). Combined actions by S\&P have a stronger impact on bank valuation than actual upgrades (with no outlook/watch adjustment), whilst for Moody's, combined actions have a weaker impact compared to actual upgrades. $C C R$ is positive and significant for Moody's, implying that positive sovereign credit actions 
by Moody's in higher rated countries have a stronger impact on bank valuations (which is related to the collateral channel).

We find evidence that international spillover is an important factor to consider. The stronger the positive sovereign rating trend is in the same world region as sovereign $j$, the stronger will be the impact of the positive sovereign rating action on the bank share prices. In the aggregate estimation, a $1 \%$ increase in the Pspillover variable leads to a $5.85 \%$ increased impact on bank CARs. Nspillover is negative (positive) and significant for S\&P and Moody's (Fitch) which means that a $1 \%$ increase in this variable leads to a $13.71 \%$ and $8.69 \%$ (28.29\%) decreased (increased) impact on bank valuations, respectively. Positive sovereign rating actions by Moody's which follow soon after previous positive sovereign rating actions to the same sovereign have a weaker impact on bank valuations.

Panel B in Table 4 presents the results of Eq. (2) for negative sovereign rating actions. Negative (positive) coefficients indicate stronger (weaker) impacts on bank valuations compared to downgrades as the reference case. We find that new rating information actions significantly decrease the two-day CAR of banks by $5.17 \%(8.04 \%)$ after negative actions by Moody's (Fitch). We find no significant evidence that rating actions, which take the sovereign from investment to speculative grade, have an additional impact on bank valuations. Negative outlook and watch actions have a $2.29 \%$ stronger impact on bank valuations compared to actual downgrades (with no outlook/watch signal) in the aggregate model. The negative and significant coefficient is driven by negative outlook and watch actions by S\&P and Moody's. On the other hand, negative outlook and watch actions and combined actions by Fitch have a $9.73 \%$ and $9.74 \%$ weaker impact on bank share prices than downgrades (with no outlook/watch adjustment). ${ }^{17} C C R$ is insignificant in all negative actions' estimations, implying no evidence of a collateral channel in linking adverse

\footnotetext{
17 This contrasts with Table 3, but greater reliance should be placed on the multivariate analysis here.
} 
sovereign credit changes with bank valuation. There is limited evidence that prior sovereign actions have an effect on bank valuations (Nspillover is only significant and positive for $\mathrm{S} \& \mathrm{P})$

We examine whether there is a disproportionate effect of positive and negative sovereign rating actions on bank valuations depending on the financial freedom level of the country. Table 5 presents the results of Eq. (3). Financial Freedom is only significant and negative in the case of S\&P (in both Panels). This is consistent with our expectations in both cases (see Section 3). This implies that for countries which experienced positive sovereign rating actions by $\mathrm{S} \& \mathrm{P}$, the positive effect on bank valuation is stronger in countries with tighter controls over their banking systems. For countries which experienced negative sovereign rating actions by $\mathrm{S} \& \mathrm{P}$, we find the negative effect on bank valuation is stronger in countries with less government control over their banking systems. Such effects are not evident for Moody's and Fitch. We also find that both positive and negative sovereign rating actions by Fitch have a stronger impact on bank valuations in countries with relatively higher levels of domestic credit. This is consistent with our expectations (see Section 3), but the effects are absent from S\&P and are in the opposite direction for Moody's negative actions.

\subsection{Guarantee channel}

We examine the guarantee channel using the $d e b t / G D P$ and the $T A / G D P$ ratios (see Section 3). Table 6 presents the results of Eq. (4). In Panel A, the coefficient for $d e b t / G D P$ is significant and negative in the aggregate model for positive sovereign rating actions. This means that positive sovereign rating actions have a stronger (weaker) impact on bank valuations in countries running relatively lower (higher) levels of government debt. This result is mainly attributable to S\&P and Moody's positive actions. In the negative actions' estimations in Panel $\mathrm{B}$, the debt/GDP coefficient is insignificant in the aggregate model, 
which suggests that the guarantee channel is only important when associated with positive sovereign rating actions and not negative sovereign rating actions. ${ }^{18}$

We also investigate the guarantee channel through the actual size of the banks' assets relative to the size of the domestic economy $(T A / G D P)$, and find that $T A / G D P$ is insignificant in all estimations. We also perform estimations with interactive variables including debt/GDP * $T A / G D P$ and find that the coefficients are insignificant in all estimations. ${ }^{19}$ These variables test whether banks of different sizes relative to the overall debt burden of a country reveal any significantly different impact on bank valuations. It is important to highlight that in the positive and negative aggregate estimations the rating channel variables remain mostly unchanged. The sovereign rating channel variables are significant factors regardless of the inclusion of the $d e b t / G D P$ and $T A / G D P$ variables.

\subsection{Discussion}

There is clear evidence of unequal responses to the three CRAs' actions. This is driven by variations in rating policy and rating models across the three largest CRAs (see Alsakka and ap Gwilym, 2012; Hill and Faff, 2010; Hill et al., 2010). Therefore, the results for the aggregate index of rating events of different CRAs should be treated with caution. In the aggregate estimations, some variables appear to be significant (e.g. positive new rating information) or insignificant (e.g. negative new rating information), while playing an important role in the individual estimations for one or two CRAs.

The results highlight strong evidence of the rating channel for the transmission of changes in sovereign risk to bank valuations in emerging countries. Contrary to some prior studies on ratings, we find that both positive and negative sovereign rating actions have a

\footnotetext{
${ }^{18}$ In Panel B, the debt/GDP coefficient is negative (positive) and significant for Moody's (Fitch). This shows that negative sovereign rating actions from Moody's (Fitch) have a stronger impact on bank valuations in countries that have relatively higher (lower) levels of overall government debt.

${ }^{19}$ In the interests of brevity, these are not tabulated.
} 
significant market impact. New rating information actions tend to have a strong impact on bank valuations. Positive new rating information actions by S\&P and Fitch increase bank share prices, while negative new rating information actions by Moody's and Fitch significantly decrease bank valuations. ${ }^{20}$ Negative outlook and watch signals are at least as important as rating downgrades in their impact on bank valuations, which suggests that these actions reveal information previously unknown to market participants due to CRAs' access to private information. ${ }^{21}$ In addition, the level of government control over the banking system influences the sensitivity of bank market valuations to recent S\&P sovereign rating actions. We find stronger effects of S\&P positive sovereign actions on bank valuations in countries with tighter controls over their banking systems. For countries which experienced negative sovereign rating actions (by $\mathrm{S} \& \mathrm{P}$ ), the negative effect on bank valuations is stronger in countries with less government control over their banking systems. Further, we find that sovereign rating actions by Fitch have a stronger impact on bank valuations in countries with relatively higher levels of domestic credit.

The collateral channel and guarantee channel only play modest roles on the basis of our evidence, but are more relevant to countries that experienced positive sovereign rating actions. Positive sovereign credit actions (by Moody's) in higher rated countries have a stronger impact on bank valuations. This implies that banks with higher ratings will be more affected by positive rating actions, because they will potentially become less dependent on

\footnotetext{
${ }^{20}$ However, for Moody's, the coefficient for new rating information is affected by the introduction of additional variables in the model. Please note that the Moody's negative action models have the fewest observations.

${ }^{21}$ The efficient market hypothesis (EMH) implies that stock prices will not adjust in response to the rating actions if the CRAs base their actions on publicly available information only. Hence, to the extent that bank share prices in emerging countries are found to respond to outlook, watch and rating signals, this implies either evidence against the semi-strong form EMH or the presence of private information available only to CRAs that is released into the public domain through credit signals (e.g. Brooks et al, 2004; Alsakka and ap Gwilym, 2012).
} 
short-term funding. Relatively lower levels of government debt are beneficial to the banking sector, since these governments are viewed by market participants to be better able to support their banking sector. The overall government debt level and its rating level are not significant factors in cases of negative sovereign rating actions' effects on bank valuations. In contrast to prior studies on developed countries, we find that larger banks in emerging countries are neither perceived as being safer nor more vulnerable in times of sovereign distress. This could be attributed to the relatively smaller banking sectors in the countries in our sample (e.g. compared to European studies). Cihak et al. (2012) identify significant variations in financial systems' features across countries and regions and over time. They present a comprehensive analysis of financial system characteristics for 205 countries, and find that developing economy financial systems tend to be much less deep, less efficient and providing less access, yet their stability has been comparable to developed country financial systems. ${ }^{22}$

\section{Conclusions}

The paper investigates the effects of sovereign rating actions by S\&P, Moody's and Fitch on the share prices of 277 banks in 19 emerging countries. We analyse three potential contagion channels between sovereign credit risk and bank valuations. There is strong evidence of the presence of a rating channel influencing the link between sovereign creditworthiness and bank valuations. The collateral channel and guarantee channel only play modest roles on the basis of our evidence, but are more relevant to emerging countries that experienced positive sovereign rating actions.

\footnotetext{
${ }^{22}$ There is also a large literature on the relationships among financial sector development, bank competition and financial stability. For example, Beck et al. (2013) highlight cross-country heterogeneity in the relationship between bank competition and bank stability, and explore market, regulatory and institutional features that can explain the variations. Cubillas and Gonzalez (2014) show that financial liberalisation increases bank risk-taking but through different channels in developed and developing countries. In the latter, liberalisation increases bank risk by expanding their opportunities to take risk.
} 
For the rating channel, we find that both positive and negative sovereign actions impact bank valuations, but the impact varies considerably across types of events and across CRAs. New rating information actions and outlook/watch actions have a strong impact on bank valuations, while $\mathrm{S} \& \mathrm{P}$ actions induce the strongest positive and significant impact on bank share prices. Negative bank cumulative abnormal returns in the pre-event window suggest that market sentiment is already negative prior to negative sovereign credit actions by Moody's and S\&P, implying a persisting effect of a downward trend. In addition, the impact of S\&P credit actions on bank valuation is influenced by the level of government control over the banking system. Further, rating actions by Fitch have a stronger impact on bank valuations in countries with relatively higher levels of domestic credit.

For the collateral channel, we find that positive sovereign credit actions (by Moody's) in higher rated countries have a stronger impact on bank valuations, because these banks will potentially become less dependent on short-term funding. For the guarantee channel, we highlight that positive actions in emerging countries which are running relatively lower levels of overall government debt are more beneficial to their banking sector than for those which are more indebted. However, the size of banks in emerging countries appears to be an insignificant factor in the link between sovereign credit risk and bank share prices.

An important implication for emerging market governments is how certain negative actions by S\&P and Moody's may exacerbate a downward trend, while negative outlook and watch signals by Fitch do not exacerbate any downward trend but impact on bank share prices. Another important finding is the information content of positive sovereign credit actions, and how these can invoke positive market sentiment for the banking system in emerging markets. Overall, we find evidence that shows a clear link between an emerging market government's external credit standing and the market valuation of its banks. 


\section{References}

Acharya, V., Drechsler, I., Schnabl, P., 2014. A pyrrhic victory? Bank bailouts and sovereign credit risk. Journal of Finance 69, 2689-2739.

Afonso, A., Furceri, D., Gomes, P., 2012. Sovereign credit ratings and financial markets linkages: Application to European data. Journal of International Money and Finance 31, 606-638.

Alsakka, R., ap Gwilym, O., 2012. Foreign exchange market reactions to sovereign credit news. Journal of International Money and Finance 31, 845-864.

Alsakka, R., ap Gwilym, O., Vu, T.N., 2014. The sovereign-bank rating channel and rating agencies' downgrades during the European debt crisis. Journal of International Money and Finance 49, 235-257.

Alter, A., Schuler, Y., 2012. Credit spread interdependencies of European states and banks during the financial crisis. Journal of Banking and Finance 36, 3444-3468.

Angeloni, C., Wolff, G., 2012. Are banks affected by their holdings of government debt? Bruegel Working Paper.

Beck, T., De Jonghe, O., Schepens, G., 2013. Bank competition and stability: Cross country heterogeneity. Journal of Financial Intermediation 22, 218-244.

Beck, T., Demirgüç-Kunt, A., Levine, R., 2006. Bank concentration, competition, and crisis: First results. Journal of Banking and Finance 30, 1581-1603.

BIS, 2011. The impact of sovereign credit risk on bank funding conditions. Committee on the Global Financial System Papers 43.

Boehmer, E., Musumeci, J., Poulsen, A., 1991. Event-study methodology under conditions of event induced variance. Journal of Financial Economics 30, 253-72.

Borensztein, E., Cowan, K., Valenzuela, P., 2013. Sovereign ceilings "lite"? The impact of sovereign ratings on corporate ratings. Journal of Banking and Finance 37, 4014-4024.

Brooks, R., Faff, R., Hillier, D., Hillier, J., 2004. The national market impact of sovereign rating changes. Journal of Banking and Finance 28, 233-250. 
Caporale, G., Matousek, R., Stewart, C., 2012. Ratings assignments: Lessons from international banks. Journal of International Money and Finance 31, 1593-1606.

Chen, S-S., Chen, H-Y., Chang, C-C., Yang, S-L., 2013. How do sovereign credit rating changes affect private investment? Journal of Banking and Finance 37, 4820-4833.

Christopher, R., Kim, J., Wu, E., 2012. Do sovereign credit ratings influence regional stock and bond market interdependencies in emerging countries? Journal of International Financial Markets, Institutions and Money 22, 1070-1089.

Cihak, M., Demirguc-Kunt, A., Feyen, E., Levine, R., 2012. Benchmarking financial systems around the world. World Bank Policy Research Working Paper 6175.

Correa, R., Lee, K-H., Sapriza, H., Suarez, G.A., 2014. Sovereign credit risk, banks' government support and bank stock returns around the world. Journal of Money, Credit and Banking 46, 93-121.

Correa, R., Sapriza, H., Zlate, A., 2012. Liquidity shocks, dollar funding costs, and the bank lending channel during the European sovereign crisis. Federal Reserve System International Finance Discussion Papers 1059.

Cubillas, E., Gonzalez, F., 2014. Financial liberalization and bank risk-taking: International evidence. Journal of Financial Stability 11, 32-48.

De Bruyckere, V., Gerhardt, M., Schepens, G., Vander Vennet, R., 2013. Bank/sovereign risk spillovers in the European debt crisis. Journal of Banking and Finance 37, 4793-4809.

Diamond, D. 1991. Debt maturity structure and liquidity risk. Quarterly Journal of Economics 106, 709-737.

Duggar, E., Emery, K., Gates, D., Paulo, S., Lemay, Y., Cailleteau, P., 2009. Emerging market corporate and sub-sovereign defaults and sovereign crises: Perspectives on country risk. Moody’s Investors Service, February.

Ferreira, M., Gama, P., 2007. Does sovereign debt ratings news spill over to international stock markets? Journal of Banking and Finance 31, 3162-82.

Gande, A., Parsley, D., 2005. News spillovers in the sovereign debt market. Journal of Financial Economics 75, 691-734. 
Hill, P., Brooks, R., Faff, R., 2010. Variations in sovereign credit quality assessments across rating agencies. Journal of Banking and Finance 34, 1327-1343.

Hill, P., Faff, R., 2010. The market impact of relative agency activity in the sovereign ratings market. Journal of Business Finance and Accounting 37, 1309-1347.

Holthausen, R., Leftwich, R., 1986. Stock price effects of bond rating changes. Journal of Financial Economics 17, 57-89.

Huang, Y-L., Shen, C-H., 2014. The sovereign effect on bank credit ratings. Journal of Financial Services Research, forthcoming.

IIF, 2014. Capital flows to emerging market economies. Institute of International Finance.

Ismailescu, I., Kazemi, H., 2010. The reaction of emerging market credit default swap spreads to sovereign credit rating changes. Journal of Banking and Finance 34, 2861-2873.

Kaminsky, G., Schmukler, S., 2002. Emerging markets instability: Do sovereign ratings affect country risk and stock return? World Bank Economic Review 16, 171-195.

Kim, J., Wu, E., 2008. Sovereign credit ratings, capital flows and financial sector development in emerging markets. Emerging Markets Review 9, 17-39.

Kim, J., Wu, E., 2011. International bank flows to emerging markets: Influence of sovereign credit ratings and their regional spillover effects. Journal of Financial Research 34, 331364.

Liu, T., Hammoudeh, S., Thompson, M., 2013. A momentum threshold model of stock prices and country risk ratings: Evidence from BRICS countries. Journal of International Financial Markets, Institutions and Money 27, 99-112.

Shen, C., Huang, Y., Hasan, I., 2012. Asymmetric benchmarking in bank credit rating. Journal of International Financial Markets, Institutions and Money 22, 171-193.

Sy, A., 2004. Rating the rating agencies: Anticipating currency crises or debt crises? Journal of Banking and Finance 28, 2845-2867.

Williams, G., Alsakka, R., ap Gwilym, O., 2013. The impact of sovereign rating actions on bank ratings in emerging markets. Journal of Banking and Finance 37, 563-577. 
Table 1- Credit rating scales

\begin{tabular}{|c|c|c|c|c|c|c|}
\hline Rating symbols & Outlook/watch & $\begin{array}{c}\text { 20-notch } \\
\text { scale }\end{array}$ & 58-point & adjustments & $\begin{array}{c}\text { 58-point CCR } \\
\text { scale }\end{array}$ & $\begin{array}{c}\text { LCCR } \\
\text { scale }\end{array}$ \\
\hline AAA/Aaа & stable watch/outlook & 20 & \multirow{3}{*}{58} & 0 & 58 & 4.060 \\
\hline AAA/Aaа & negative outlook & 20 & & -1 & 57 & 3.350 \\
\hline AAA/Aaа & negative watch & 20 & & -2 & 56 & 2.927 \\
\hline $\mathrm{AA}+/ \mathrm{Aa} 1$ & positive watch & 19 & \multirow{5}{*}{55} & 2 & 57 & 3.350 \\
\hline $\mathrm{AA}+/ \mathrm{Aa} 1$ & positive outlook & 19 & & 1 & 56 & 2.927 \\
\hline $\mathrm{AA}+/ \mathrm{Aa} 1$ & stable watch/outlook & 19 & & 0 & 55 & 2.621 \\
\hline $\mathrm{AA}+/ \mathrm{Aa} 1$ & negative outlook & 19 & & -1 & 54 & 2.380 \\
\hline $\mathrm{AA}+/ \mathrm{Aa} 1$ & negative watch & 19 & & -2 & 53 & 2.179 \\
\hline $\mathrm{AA} / \mathrm{Aa} 2$ & positive watch & 18 & \multirow{5}{*}{52} & 2 & 54 & 2.380 \\
\hline $\mathrm{AA} / \mathrm{Aa} 2$ & positive outlook & 18 & & 1 & 53 & 2.179 \\
\hline $\mathrm{AA} / \mathrm{Aa} 2$ & stable watch/outlook & 18 & & 0 & 52 & 2.005 \\
\hline $\mathrm{AA} / \mathrm{Aa} 2$ & negative outlook & 18 & & -1 & 51 & 1.852 \\
\hline $\mathrm{AA} / \mathrm{Aa} 2$ & negative watch & 18 & & -2 & 50 & 1.715 \\
\hline $\mathrm{AA}-/ \mathrm{Aa} 3$ & positive watch & 17 & \multirow{5}{*}{49} & 2 & 51 & 1.852 \\
\hline AA-/Aa3 & positive outlook & 17 & & 1 & 50 & 1.715 \\
\hline AA-/Aa3 & stable watch/outlook & 17 & & 0 & 49 & 1.589 \\
\hline $\mathrm{AA}-/ \mathrm{Aa} 3$ & negative outlook & 17 & & -1 & 48 & 1.473 \\
\hline AA-/Aa3 & negative watch & 17 & & -2 & 47 & 1.365 \\
\hline $\mathrm{A}+/ \mathrm{A} 1$ & positive watch & 16 & \multirow{5}{*}{46} & 2 & 48 & 1.473 \\
\hline $\mathrm{A}+/ \mathrm{A} 1$ & positive outlook & 16 & & 1 & 47 & 1.365 \\
\hline $\mathrm{A}+/ \mathrm{A} 1$ & stable watch/outlook & 16 & & 0 & 46 & 1.264 \\
\hline $\mathrm{A}+/ \mathrm{A} 1$ & negative outlook & 16 & & -1 & 45 & 1.168 \\
\hline$A+/ A 1$ & negative watch & 16 & & -2 & 44 & 1.076 \\
\hline $\mathrm{A} / \mathrm{A} 2$ & positive watch & 15 & \multirow{5}{*}{43} & 2 & 45 & 1.168 \\
\hline $\mathrm{A} / \mathrm{A} 2$ & positive outlook & 15 & & 1 & 44 & 1.076 \\
\hline $\mathrm{A} / \mathrm{A} 2$ & stable watch/outlook & 15 & & 0 & 43 & 0.989 \\
\hline $\mathrm{A} / \mathrm{A} 2$ & negative outlook & 15 & & -1 & 42 & 0.904 \\
\hline $\mathrm{A} / \mathrm{A} 2$ & negative watch & 15 & & -2 & 41 & 0.823 \\
\hline A-/A3 & positive watch & 14 & \multirow{5}{*}{40} & 2 & 42 & 0.904 \\
\hline A-/A3 & positive outlook & 14 & & 1 & 41 & 0.823 \\
\hline A-/A3 & stable watch/outlook & 14 & & 0 & 40 & 0.744 \\
\hline A-/A3 & negative outlook & 14 & & -1 & 39 & 0.668 \\
\hline A-/A3 & negative watch & 14 & & -2 & 38 & 0.593 \\
\hline $\mathrm{BBB}+/ \mathrm{Baa} 1$ & positive watch & 13 & \multirow{5}{*}{37} & 2 & 39 & 0.668 \\
\hline $\mathrm{BBB}+/ \mathrm{Baa} 1$ & positive outlook & 13 & & 1 & 38 & 0.593 \\
\hline $\mathrm{BBB}+/ \mathrm{Baa} 1$ & stable watch/outlook & 13 & & 0 & 37 & 0.520 \\
\hline $\mathrm{BBB}+/ \mathrm{Baa} 1$ & negative outlook & 13 & & -1 & 36 & 0.448 \\
\hline $\mathrm{BBB}+/ \mathrm{Baa} 1$ & negative watch & 13 & & -2 & 35 & 0.377 \\
\hline $\mathrm{BBB} / \mathrm{Baa} 2$ & positive watch & 12 & \multirow{5}{*}{34} & 2 & 36 & 0.448 \\
\hline $\mathrm{BBB} / \mathrm{Baa} 2$ & positive outlook & 12 & & 1 & 35 & 0.377 \\
\hline $\mathrm{BBB} / \mathrm{Baa} 2$ & stable watch/outlook & 12 & & 0 & 34 & 0.307 \\
\hline $\mathrm{BBB} / \mathrm{Baa} 2$ & negative outlook & 12 & & -1 & 33 & 0.238 \\
\hline $\mathrm{BBB} / \mathrm{Baa} 2$ & negative watch & 12 & & -2 & 32 & 0.170 \\
\hline BBB-/Baa3 & positive watch & 11 & \multirow{5}{*}{31} & 2 & 33 & 0.238 \\
\hline BBB-/Baa3 & positive outlook & 11 & & 1 & 32 & 0.170 \\
\hline BBB-/Baa3 & stable watch/outlook & 11 & & 0 & 31 & 0.102 \\
\hline BBB-/Baa3 & negative outlook & 11 & & -1 & 30 & 0.034 \\
\hline BBB-/Baa3 & negative watch & 11 & & -2 & 29 & -0.034 \\
\hline $\mathrm{BB}+/ \mathrm{Ba} 1$ & positive watch & 10 & \multirow{5}{*}{28} & 2 & 30 & 0.034 \\
\hline $\mathrm{BB}+/ \mathrm{Ba} 1$ & positive outlook & 10 & & 1 & 29 & -0.034 \\
\hline $\mathrm{BB}+/ \mathrm{Ba} 1$ & stable watch/outlook & 10 & & 0 & 28 & -0.102 \\
\hline $\mathrm{BB}+/ \mathrm{Ba} 1$ & negative outlook & 10 & & -1 & 27 & -0.170 \\
\hline $\mathrm{BB}+/ \mathrm{Ba} 1$ & negative watch & 10 & & -2 & 26 & -0.238 \\
\hline $\mathrm{BB} / \mathrm{Ba} 2$ & positive watch & 9 & \multirow{5}{*}{25} & 2 & 27 & -0.170 \\
\hline $\mathrm{BB} / \mathrm{Ba} 2$ & positive outlook & 9 & & 1 & 26 & -0.238 \\
\hline $\mathrm{BB} / \mathrm{Ba} 2$ & stable watch/outlook & 9 & & 0 & 25 & -0.307 \\
\hline $\mathrm{BB} / \mathrm{Ba} 2$ & negative outlook & 9 & & -1 & 24 & -0.377 \\
\hline $\mathrm{BB} / \mathrm{Ba} 2$ & negative watch & 9 & & -2 & 23 & -0.448 \\
\hline
\end{tabular}


Table 1 continued.

\begin{tabular}{|c|c|c|c|c|c|c|}
\hline Rating symbols & Outlook/watch & $\begin{array}{l}\text { 20-notch } \\
\text { scale }\end{array}$ & 58-point & adjustments & $\begin{array}{c}\text { 58-point CCR } \\
\text { scale }\end{array}$ & $\begin{array}{c}\text { LCCR } \\
\text { scale }\end{array}$ \\
\hline $\mathrm{BB}-/ \mathrm{Ba} 3$ & positive watch & 8 & & 2 & 24 & -0.377 \\
\hline $\mathrm{BB}-/ \mathrm{Ba} 3$ & positive outlook & 8 & & 1 & 23 & -0.448 \\
\hline $\mathrm{BB}-/ \mathrm{Ba} 3$ & stable watch/outlook & 8 & 22 & 0 & 22 & -0.520 \\
\hline $\mathrm{BB}-/ \mathrm{Ba} 3$ & negative outlook & 8 & & -1 & 21 & -0.593 \\
\hline BB-/Ba3 & negative watch & 8 & & -2 & 20 & -0.668 \\
\hline $\mathrm{B}+/ \mathrm{B} 1$ & positive watch & 7 & & 2 & 21 & -0.593 \\
\hline $\mathrm{B}+/ \mathrm{B} 1$ & positive outlook & 7 & & 1 & 20 & -0.668 \\
\hline $\mathrm{B}+/ \mathrm{B} 1$ & stable watch/outlook & 7 & 19 & 0 & 19 & -0.744 \\
\hline $\mathrm{B}+/ \mathrm{B} 1$ & negative outlook & 7 & & -1 & 18 & -0.823 \\
\hline $\mathrm{B}+/ \mathrm{B} 1$ & negative watch & 7 & & -2 & 17 & -0.904 \\
\hline $\mathrm{B} / \mathrm{B} 2$ & positive watch & 6 & & 2 & 18 & -0.823 \\
\hline $\mathrm{B} / \mathrm{B} 2$ & positive outlook & 6 & & 1 & 17 & -0.904 \\
\hline $\mathrm{B} / \mathrm{B} 2$ & stable watch/outlook & 6 & 16 & 0 & 16 & -0.989 \\
\hline $\mathrm{B} / \mathrm{B} 2$ & negative outlook & 6 & & -1 & 15 & -1.076 \\
\hline $\mathrm{B} / \mathrm{B} 2$ & negative watch & 6 & & -2 & 14 & -1.168 \\
\hline B-/B3 & positive watch & 5 & & 2 & 15 & -1.076 \\
\hline B-/B3 & positive outlook & 5 & & 1 & 14 & -1.168 \\
\hline B-/B3 & stable watch/outlook & 5 & 13 & 0 & 13 & -1.264 \\
\hline B-/B3 & negative outlook & 5 & & -1 & 12 & -1.365 \\
\hline B-/B3 & negative watch & 5 & & -2 & 11 & -1.473 \\
\hline $\mathrm{CCC}+/ \mathrm{Caa} 1$ & positive watch & 4 & & 2 & 12 & -1.365 \\
\hline $\mathrm{CCC}+/ \mathrm{Caa} 1$ & positive outlook & 4 & & 1 & 11 & -1.473 \\
\hline $\mathrm{CCC}+/ \mathrm{Caa} 1$ & stable watch/outlook & 4 & 10 & 0 & 10 & -1.589 \\
\hline $\mathrm{CCC}+/ \mathrm{Caa} 1$ & negative outlook & 4 & & -1 & 9 & -1.715 \\
\hline $\mathrm{CCC}+/ \mathrm{Caa} 1$ & negative watch & 4 & & -2 & 8 & -1.852 \\
\hline $\mathrm{CCC} / \mathrm{Caa} 2$ & positive watch & 3 & & 2 & 9 & -1.715 \\
\hline $\mathrm{CCC} / \mathrm{Caa} 2$ & positive outlook & 3 & & 1 & 8 & -1.852 \\
\hline $\mathrm{CCC} / \mathrm{Caa} 2$ & stable watch/outlook & 3 & 7 & 0 & 7 & -2.005 \\
\hline $\mathrm{CCC} / \mathrm{Caa} 2$ & negative outlook & 3 & & -1 & 6 & -2.179 \\
\hline $\mathrm{CCC} / \mathrm{Caa} 2$ & negative watch & 3 & & -2 & 5 & -2.380 \\
\hline CCC-/Caa3 & positive watch & 2 & & 2 & 6 & -2.179 \\
\hline CCC-/Caa3 & positive outlook & 2 & & 1 & 5 & -2.380 \\
\hline CCC-/Caa3 & stable watch/outlook & 2 & 4 & 0 & 4 & -2.621 \\
\hline CCC-/Caa3 & negative outlook & 2 & & -1 & 3 & -2.927 \\
\hline CCC-/Caa3 & negative watch & 2 & & -2 & 2 & -3.350 \\
\hline $\begin{array}{l}\mathrm{CC}, \mathrm{SD}, \mathrm{D} / \\
\mathrm{Ca}, \mathrm{C} / \mathrm{RD}, \mathrm{D}\end{array}$ & & & 1 & & 1 & -4.060 \\
\hline
\end{tabular}

Table 1 presents the transformation of the alphabetical rating scale to 20-notch, 58-point CCR and

LCCR numerical rating scales. The LCCR is based on a logit-type transformation (to address possible rating scale non-linearity) to the 58-point CCR, whereby LCCR = ln [CCR/ (59-CCR)] (See Sy, 2004). While different categories can generate the same CCR score, there are no rating migrations between such categories. E.g. a $\mathrm{BB} /$ positive watch rated entity does not migrate to $\mathrm{BB}+$ /negative outlook. 


\begin{tabular}{|c|c|c|c|c|}
\hline & & S\&P & Moody's & Fitch \\
\hline 1 & No. of countries & 19 & 19 & 18 \\
\hline 2 & Upgrades (solo) & 39 & 38 & 36 \\
\hline 3 & Downgrades (solo) & 8 & 4 & 8 \\
\hline 4 & Total rating changes (solo) & 47 & 42 & 44 \\
\hline 5 & Positive outlook actions (solo) & 49 & 32 & 40 \\
\hline 6 & Negative outlook actions (solo) & 31 & 11 & 23 \\
\hline 7 & Total outlook actions (solo) & 80 & 43 & 63 \\
\hline 8 & Positive watch actions (solo) & 2 & 25 & 4 \\
\hline 9 & Negative watch actions (solo) & 4 & 2 & 4 \\
\hline 10 & Total watch actions (solo) & 6 & 27 & 8 \\
\hline 11 & Upgrades and positive outlook action & 8 & 5 & 2 \\
\hline 12 & Downgrades and negative outlook action & 9 & 1 & 8 \\
\hline 13 & Downgrades and negative watch action & 4 & 4 & 3 \\
\hline 14 & Total combined actions & 21 & 10 & 13 \\
\hline 15 & Total positive actions & 98 & 100 & 82 \\
\hline 16 & Total negative actions & 56 & 22 & 46 \\
\hline 17 & Total sovereign rating actions & 154 & 122 & 128 \\
\hline 18 & Clustered positive events & 21 & 24 & 22 \\
\hline 19 & Clustered negative events & 22 & 12 & 17 \\
\hline 20 & Independent positive events & 77 & 76 & 60 \\
\hline 21 & Independent negative events & 34 & 10 & 29 \\
\hline 22 & Positive new information actions & 47 & 40 & 30 \\
\hline 23 & Negative new information actions & 37 & 16 & 20 \\
\hline 24 & New information as $\%$ of total actions ((Rows $22+23) /$ Row 17$)$ & $54 \%$ & $46 \%$ & $39 \%$ \\
\hline
\end{tabular}

This table presents summary statistics for the dataset, which consists of daily information on long-term foreigncurrency ratings, outlooks and watch for emerging market sovereigns rated by Standard and Poor's, Moody's and Fitch during the period $1^{\text {st }}$ January 2001 to $30^{\text {th }}$ September 2011. See footnote 4 for the list of countries. See Section 4.2 for the definitions of independent and clustered events and new information actions. 


\begin{tabular}{|c|c|c|c|c|c|c|c|c|c|c|c|c|c|c|}
\hline & & & \multicolumn{4}{|c|}{ CARs around $\mathrm{S} \& \mathrm{P}$ rating actions } & \multicolumn{4}{|c|}{ CARs around Moody's rating actions } & \multicolumn{4}{|c|}{ CARs around Fitch rating actions } \\
\hline & & & $\mathrm{N}$ & Pre-event & Event & Post- & $\mathrm{N}$ & Pre-event & Event & Post- & $\mathrm{N}$ & Pre-event & Event & Post-event \\
\hline \multirow{14}{*}{ 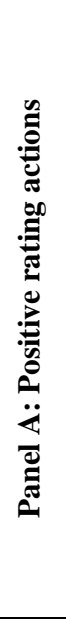 } & 1 & All actions & 1248 & 0.0178 & 0.0091 & 0.0043 & 1186 & -0.0048 & -0.0028 & -0.0002 & 946 & 0.0009 & -0.0077 & -0.0021 \\
\hline & & & & $4.51 * *$ & $6.67 * *$ & 0.85 & & $-2.00 *$ & $-2.58 * *$ & -0.46 & & 0.06 & $-5.06 * *$ & -1.20 \\
\hline & 2 & Actual upgrades only & 440 & 0.0226 & 0.0092 & -0.0024 & 457 & -0.0091 & -0.0043 & -0.0101 & 428 & 0.0015 & -0.0035 & 0.0106 \\
\hline & & & & $4.22 * *$ & $5.43 * *$ & -1.66 & & $-1.99 *$ & $-2.44 *$ & $-2.53^{*}$ & & 1.02 & -1.39 & $2.49 *$ \\
\hline & 3 & Combined actions only & 112 & -0.0047 & 0.0177 & -0.0082 & 53 & 0.0028 & -0.0108 & -0.0206 & 31 & 0.0411 & 0.0073 & 0.0519 \\
\hline & & & & -0.25 & $3.59 * *$ & -1.22 & & 0.22 & -1.49 & $-2.73^{* *}$ & & $2.65 * *$ & 1.45 & $3.33 * *$ \\
\hline & 4 & Outlook \& watch action only & 696 & 0.0185 & 0.0077 & 0.0106 & 676 & -0.0025 & -0.0011 & 0.0081 & 487 & -0.0022 & -0.0124 & -0.0166 \\
\hline & & & & $3.12 * *$ & $3.23 * *$ & $2.57 *$ & & -0.84 & -0.92 & $2.03 *$ & & -1.87 & $-6.75 * *$ & $-4.45^{* *}$ \\
\hline & 5 & New rating information & 579 & 0.0272 & 0.0172 & 0.0092 & 460 & -0.0140 & 0.0029 & -0.0001 & 400 & -0.0136 & 0.0010 & -0.0116 \\
\hline & & & & $3.87 * *$ & $7.92 * *$ & 1.78 & & $-4.72 * *$ & 1.30 & -0.10 & & $-2.00 *$ & 0.52 & $-2.82 * *$ \\
\hline & 6 & Independent actions & 1006 & 0.0167 & 0.0093 & 0.0041 & 888 & -0.0043 & -0.0011 & -0.0028 & 675 & -0.0034 & -0.0032 & -0.0029 \\
\hline & & & & $4.36^{* *}$ & $5.99 * *$ & 0.63 & & -1.31 & -1.10 & -1.70 & & -1.42 & $-2.69 * *$ & -1.72 \\
\hline & 7 & Clustered actions & 242 & 0.0226 & 0.0081 & 0.0055 & 298 & -0.0063 & -0.0077 & 0.0076 & 271 & 0.0116 & -0.0191 & -0.0001 \\
\hline & & & & 1.44 & $2.93 * *$ & 0.69 & & -1.77 & $-3.28 * *$ & $2.36^{*}$ & & $2.22 *$ & $-4.76 * *$ & -0.72 \\
\hline \multirow{14}{*}{ 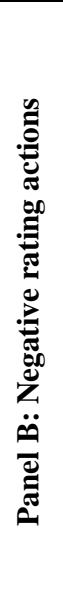 } & 8 & All actions & 641 & -0.0467 & -0.0067 & 0.0168 & 225 & -0.0444 & -0.0089 & 0.0015 & 473 & -0.0066 & -0.0078 & 0.0088 \\
\hline & & & & $-7.66 * *$ & -1.89 & $1.97 *$ & & $-4.44 * *$ & $-4.06 * *$ & 0.26 & & -1.20 & $-3.08 * *$ & 0.84 \\
\hline & 9 & Actual downgrades only & 65 & -0.0284 & 0.0090 & 0.0007 & 49 & -0.0046 & -0.0147 & 0.0347 & 81 & 0.0770 & 0.0064 & 0.0055 \\
\hline & & & & $-2.06^{*}$ & 1.11 & 1.29 & & -0.48 & $-2.80 * *$ & 1.48 & & $4.00 * *$ & 1.88 & 0.09 \\
\hline & 10 & Combined actions only & 119 & -0.0480 & 0.0014 & 0.0373 & 37 & -0.1136 & -0.0111 & -0.0197 & 101 & -0.0554 & -0.0032 & 0.0626 \\
\hline & & & & $-10.12 * *$ & $2.49 *$ & 0.48 & & $-4.47 * *$ & $-2.70 * *$ & -1.69 & & $-2.40 *$ & -1.26 & 1.42 \\
\hline & 11 & Outlook \& watch action only & 457 & -0.0490 & -0.0110 & 0.0137 & 139 & -0.0400 & -0.0063 & -0.0046 & 291 & -0.0129 & -0.0133 & -0.0090 \\
\hline & & & & $-6.22 * *$ & $-2.10 *$ & $2.40 *$ & & $-3.80 * *$ & $-2.29 *$ & -0.75 & & -1.52 & $-3.73 * *$ & -1.95 \\
\hline & 12 & New rating information & 495 & -0.0405 & -0.0060 & 0.0200 & 155 & -0.0417 & -0.0089 & -0.0110 & 230 & -0.0264 & -0.0040 & 0.0192 \\
\hline & & & & $-5.35 * *$ & -1.25 & $2.13^{*}$ & & $-2.84 * *$ & $-3.24 * *$ & -0.94 & & $-2.31 *$ & -1.55 & 1.19 \\
\hline & 13 & Independent actions & 411 & -0.0400 & -0.0010 & 0.0130 & 87 & 0.0104 & -0.0019 & -0.0230 & 308 & 0.0195 & -0.0047 & 0.0000 \\
\hline & & & & $-5.05 * *$ & -0.06 & $2.38 *$ & & 1.91 & -0.92 & -1.28 & & 0.57 & $-2.07 *$ & 0.61 \\
\hline & 14 & Clustered actions & 230 & -0.0586 & -0.0169 & 0.0234 & 138 & -0.0789 & -0.0134 & 0.0169 & 165 & -0.0552 & -0.0135 & 0.0253 \\
\hline & & & & $-6.61 * *$ & $-3.32 * *$ & 0.37 & & $-7.63 * *$ & $-4.58 * *$ & 1.24 & & $-4.91 * *$ & $-2.30 *$ & 1.37 \\
\hline
\end{tabular}

This table presents the results of the average bank cumulative abnormal returns (CARs) around the time of sovereign rating actions by S\&P, Moody's and Fitch to 19 (18 for Fitch) emerging market countries in the period $1^{\text {st }}$ January 2001 to $30^{\text {th }}$ September 2011 . See footnote 4 for the list of countries. We report the 10 -day pre-event $(-10$, -1), the two-day event $(0,+1)$ and the 10 -day post-event $(+2,+11)$ window CARs. Mean-adjusted returns calculations are specified in Section 4.3. $t$-statistics are the Boehmer at al. (1991) standardized cross-sectional $t$-statistics, and are reported beneath each coefficient. ** Significant at the $1 \%$ level; * significant at the $5 \%$ level. 
Table 4 - The roles of sovereign rating and collateral channels - Eq. (2)

\begin{tabular}{|c|c|c|c|c|c|c|c|c|c|}
\hline \multicolumn{5}{|c|}{ Panel A - Positive sovereign rating actions } & \multicolumn{5}{|c|}{ Panel B - Negative sovereign rating actions } \\
\hline Variables & Aggregate & $\mathrm{S} \& \mathrm{P}$ & Moody's & Fitch & Variables & Aggregate & $\mathrm{S} \& \mathrm{P}$ & Moody's & Fitch \\
\hline \multirow[t]{2}{*}{ New rating information } & 0.0133 & 0.0069 & 0.0084 & 0.0113 & New rating information & -0.0069 & -0.0014 & -0.0517 & -0.0804 \\
\hline & $7.75 * *$ & $2.09 *$ & 1.87 & $2.14 *$ & & -1.27 & -0.10 & $-2.70 * *$ & $-3.07 * *$ \\
\hline \multirow[t]{2}{*}{ Speculative to investment } & 0.0205 & 0.0369 & -0.0182 & 0.0712 & Investment to speculative & 0.0022 & -0.0398 & n.a. & 0.0743 \\
\hline & $4.83 * *$ & $4.68 * *$ & $-2.28 *$ & $6.88 * *$ & & 0.16 & -1.60 & & 1.49 \\
\hline \multirow[t]{2}{*}{ Outlook/watch actions } & -0.0003 & 0.0005 & 0.0041 & -0.0136 & Outlook/watch actions & -0.0229 & -0.0375 & -0.0238 & 0.0973 \\
\hline & -0.16 & 0.14 & 1.57 & $-4.01 * *$ & & $-4.09 * *$ & $-2.17 *$ & $-2.52 *$ & $2.58 *$ \\
\hline \multirow[t]{2}{*}{ Combined actions } & 0.0079 & 0.0197 & -0.0148 & -0.0242 & Combined actions & 0.0002 & -0.0031 & -0.0172 & 0.0974 \\
\hline & 1.87 & $2.63 * *$ & $-2.55^{*}$ & $-2.30 *$ & & 0.03 & -0.23 & -1.29 & $2.41 *$ \\
\hline \multirow[t]{2}{*}{ CCR } & 0.0000 & 0.0001 & 0.0041 & -0.0009 & $\mathrm{CCR}$ & -0.0017 & -0.0004 & -0.0028 & -0.0015 \\
\hline & 0.07 & 0.09 & $4.81 * *$ & -1.05 & & -1.94 & -0.19 & -1.88 & -0.82 \\
\hline \multirow[t]{2}{*}{ Pspillover } & 0.0585 & 0.1587 & 0.0150 & 0.0580 & Pspillover & 0.0235 & 0.1476 & n.a. & -0.3282 \\
\hline & $6.95^{* *}$ & $6.43 * *$ & 1.62 & $3.37 * *$ & & 1.24 & 1.65 & & -1.39 \\
\hline \multirow[t]{2}{*}{ Nspillover } & -0.0449 & -0.1371 & -0.0869 & 0.2829 & Nspillover & 0.0167 & 0.0617 & n.a. & 0.0918 \\
\hline & -1.48 & $-2.11 *$ & $-2.14 *$ & $2.88 * *$ & & 1.38 & $2.83 * *$ & & 1.32 \\
\hline \multirow[t]{2}{*}{ Plagged } & -0.0112 & -0.0537 & -0.0765 & -0.0452 & Nlagged & 0.0076 & 0.0729 & n.a. & 0.0413 \\
\hline & -0.74 & -1.75 & $-2.54 *$ & -1.09 & & 0.81 & 0.85 & & 1.27 \\
\hline \multirow[t]{2}{*}{ Constant } & 0.0037 & 0.0383 & -0.0876 & -0.0383 & Constant & 0.0314 & -0.0038 & 0.2029 & -0.0856 \\
\hline & 0.28 & 1.72 & $-3.56 * *$ & -1.77 & & $1.98 *$ & -0.13 & $2.51 *$ & -1.49 \\
\hline Country and Year dummies & Yes & Yes & Yes & Yes & Country and Year dummies & Yes & Yes & Yes & Yes \\
\hline $\mathrm{N}$ & 3348 & 1237 & 1168 & 943 & $\mathrm{~N}$ & 1205 & 617 & 225 & 431 \\
\hline $\mathrm{R}^{2}$ & 0.070 & 0.162 & 0.130 & 0.271 & $\mathrm{R}^{2}$ & 0.076 & 0.127 & 0.320 & 0.304 \\
\hline
\end{tabular}

This table presents the coefficient estimates of Eq. (2) using data samples of emerging market countries rated by S\&P, Moody's and Fitch during January 2001 to September 2011. $C A R_{i j t}$ : the dependent variable, is the mean-adjusted cumulative abnormal return of bank $i$ in sovereign $j$ in the two-day event window $(0,+1)$ around sovereign rating actions at time $t$. New rating information is a dummy variable that indicates whether a rating action provides new information. Speculative to investment (Investment to speculative) is a dummy variable that indicates whether a rating action takes sovereign $j$ from speculative (investment) grade to investment (speculative) grade. Out/watch is a dummy variable that indicates whether the rating action is a change to the outlook or watch status of sovereign $j$, with no rating change. Combined is a dummy variable that indicates whether sovereign $j$ is upgraded (downgraded) and simultaneously placed on positive (negative) outlook or watch status. Combined can also take a value of 1 , if sovereign $j$ is subject to more than one rating action by more than one CRA on the same day. CCR is sovereign $j$ 's rating level according to the 58-point numerical scale immediately prior to the rating action. Pspillover (Nspillover) is a positive (negative) net total change in $L C C R$ (see footnote 15 and Table 1 ) in the past 10 trading days from all three CRAs of the countries in the same world region as the event sovereign $(s)$. The absolute value of Nspillover is employed for ease of interpretation. Plagged (Nlagged) is a positive (negative) net total change in LCCR of sovereign $j$ in the last 10 trading days from all three CRAs. Full sets of event Country and Year dummies are included. 'n.a.' is not applicable due to lack of observations. We apply Huber-White robust standard errors, and t-statistics are reported beneath each coefficient.

** Significant at $1 \%$ level; * significant at $5 \%$ level. 
Table 5 - The roles of financial freedom and domestic credit - Eq. (3)

\begin{tabular}{|c|c|c|c|c|c|c|c|c|c|}
\hline \multicolumn{5}{|c|}{ Panel A - Positive sovereign rating actions } & \multicolumn{5}{|c|}{ Panel B - Negative sovereign rating actions } \\
\hline Variables & Aggregate & $\mathrm{S} \& \mathrm{P}$ & Moody's & Fitch & Variables & Aggregate & $\mathrm{S} \& \mathrm{P}$ & Moody's & Fitch \\
\hline \multirow[t]{2}{*}{ New rating information } & 0.0130 & 0.0087 & 0.0096 & 0.0090 & New rating information & -0.0066 & 0.0123 & 0.0112 & -0.0518 \\
\hline & $7.56^{* *}$ & $2.62 * *$ & $2.11 *$ & 1.61 & & -1.23 & 0.81 & 0.59 & -1.76 \\
\hline \multirow[t]{2}{*}{ Speculative to investment } & 0.0200 & 0.0331 & -0.0160 & 0.0640 & Investment to speculative & 0.0247 & -0.0096 & n.a. & 0.0525 \\
\hline & $4.69 * *$ & $4.07 * *$ & -1.95 & $5.80 * *$ & & 1.80 & -0.39 & & 1.26 \\
\hline \multirow{2}{*}{ Outlook/watch actions } & 0.0003 & 0.0034 & 0.0039 & -0.0138 & Outlook/watch actions & -0.0178 & -0.0275 & -0.0238 & 0.0836 \\
\hline & 0.15 & 0.94 & 1.42 & $-4.21 * *$ & & $-3.11 * *$ & -1.67 & $-2.52 *$ & $2.03 *$ \\
\hline \multirow[t]{2}{*}{ Combined actions } & 0.0086 & 0.0191 & -0.0127 & -0.0290 & Combined actions & 0.0012 & 0.0070 & -0.0172 & 0.0767 \\
\hline & $2.00 *$ & $2.53 *$ & $-2.13^{*}$ & $-2.67 * *$ & & 0.17 & 0.50 & -1.29 & 1.62 \\
\hline \multirow[t]{2}{*}{ CCR } & 0.0001 & 0.0005 & 0.0040 & -0.0013 & CCR & -0.0014 & 0.0002 & -0.0028 & -0.0010 \\
\hline & 0.16 & 0.40 & $4.82 * *$ & -1.55 & & -1.60 & 0.09 & -1.88 & -0.56 \\
\hline \multirow[t]{2}{*}{ Pspillover } & 0.0596 & 0.1713 & 0.0152 & 0.0469 & Pspillover & 0.0322 & 0.1758 & n.a. & -0.3430 \\
\hline & $7.08 * *$ & $6.98 * *$ & 1.65 & $2.70 * *$ & & 1.70 & $2.16^{*}$ & & -1.33 \\
\hline \multirow[t]{2}{*}{ Nspillover } & -0.0574 & -0.1916 & -0.0825 & 0.2926 & Nspillover & 0.0267 & 0.0725 & n.a. & 0.0926 \\
\hline & -1.81 & $-2.76^{* *}$ & -1.65 & $2.93 * *$ & & $2.20 *$ & $3.77 * *$ & & 1.25 \\
\hline \multirow[t]{2}{*}{ Plagged } & -0.0085 & -0.0286 & -0.0766 & -0.0419 & Nlagged & 0.0097 & 0.0797 & n.a. & 0.0403 \\
\hline & -0.56 & -0.93 & $-2.54 *$ & -1.00 & & 0.96 & 0.95 & & 1.13 \\
\hline \multirow[t]{2}{*}{ Financial freedom } & -0.0130 & -0.0550 & -0.0035 & -0.0001 & Financial freedom & 0.0285 & -0.1595 & 0.0463 & 0.0065 \\
\hline & -1.95 & $-4.78 * *$ & -0.23 & -0.01 & & 1.32 & $-2.97 * *$ & 1.35 & 0.04 \\
\hline \multirow[t]{2}{*}{ Domestic credit/GDP } & -0.0001 & 0.0005 & -0.0004 & 0.0009 & Domestic credit/GDP & -0.0022 & 0.0026 & 0.0014 & -0.0039 \\
\hline & -0.55 & 1.64 & -1.36 & $2.73 * *$ & & $-5.96 * *$ & 1.40 & $2.04 *$ & $-2.74 * *$ \\
\hline \multirow[t]{2}{*}{ Constant } & 0.0553 & 0.2356 & -0.0626 & -0.0498 & Constant & -0.0461 & 0.5374 & -0.1953 & -0.0296 \\
\hline & 1.81 & $5.15 * *$ & -0.94 & -0.85 & & -0.55 & $3.02 * *$ & -1.19 & -0.04 \\
\hline Country dummies & Yes & Yes & Yes & Yes & Country dummies & Yes & Yes & Yes & Yes \\
\hline Year dummies & Yes & Yes & Yes & Yes & Year dummies & Yes & Yes & Yes & Yes \\
\hline $\mathrm{N}$ & 3348 & 1237 & 1168 & 943 & $\mathrm{~N}$ & 1205 & 617 & 225 & 431 \\
\hline $\mathrm{R}^{2}$ & 0.071 & 0.177 & 0.131 & 0.278 & $\mathrm{R}^{2}$ & 0.097 & 0.137 & 0.320 & 0.358 \\
\hline
\end{tabular}

This table presents the results of Eq. (3) using data samples of emerging market countries rated by S\&P, Moody's and Fitch during January 2001 to September 2011 . $C A R_{i j t}$ : the dependent variable, is the mean-adjusted cumulative abnormal return of bank $i$ in sovereign $j$ in the two-day event window $(0,+1)$ around sovereign rating actions at time t. Financial freedom is the financial freedom of sovereign $j$ according The Heritage Foundation's Financial Freedom index as defined in Section 4.4. Domestic credit/GDP is the domestic credit provided by the financial sector as a share of GDP. All other variables are the same as specified in Table 4. We apply Huber-White robust standard errors, and $\mathrm{t}$-statistics are reported beneath each coefficient. ** Significant at $1 \%$ level; * significant at $5 \%$ level. 
Table 6- The role of a guarantee channel - Eq. (4)

\begin{tabular}{|c|c|c|c|c|c|c|c|c|c|}
\hline \multicolumn{5}{|c|}{ Panel A - Positive sovereign rating actions } & \multicolumn{5}{|c|}{ Panel B - Negative sovereign rating actions } \\
\hline Variables & Aggregate & $\mathrm{S} \& \mathrm{P}$ & Moody's & Fitch & Variables & Aggregate & S\&P & Moody's & Fitch \\
\hline \multirow[t]{2}{*}{ New rating information } & 0.0135 & 0.0093 & 0.008 & 0.0119 & New rating information & -0.008 & -0.0001 & 0.0743 & -0.0645 \\
\hline & $7.70 * *$ & $2.69 * *$ & 1.69 & $2.02 *$ & & -1.39 & -0.01 & $4.36 * *$ & $-2.06^{*}$ \\
\hline \multirow[t]{2}{*}{ Speculative to investment } & 0.0225 & 0.0384 & -0.0127 & 0.0698 & Investment to speculative & 0.0051 & 0.0352 & n.a. & 0.0813 \\
\hline & $4.98 * *$ & $4.58 * *$ & -1.58 & $5.97 * *$ & & 0.28 & 1.38 & & 1.73 \\
\hline \multirow[t]{2}{*}{ Outlook/watch actions } & -0.0016 & -0.0006 & 0.0023 & -0.0149 & Outlook/watch actions & -0.0227 & -0.0526 & -0.0243 & 0.0616 \\
\hline & -0.81 & -0.15 & 0.79 & $-4.16^{* *}$ & & $-3.58 * *$ & $-2.74 * *$ & $-2.52 *$ & 1.30 \\
\hline \multirow[t]{2}{*}{ Combined actions } & 0.0074 & 0.0174 & -0.0171 & -0.0264 & Combined actions & -0.001 & -0.0063 & -0.0181 & 0.0391 \\
\hline & 1.70 & $2.30 *$ & $-2.88 * *$ & $-2.34 *$ & & -0.13 & -0.44 & -1.37 & 0.73 \\
\hline \multirow[t]{2}{*}{$\mathrm{CCR}$} & -0.0001 & -0.0003 & 0.0037 & -0.0004 & CCR & -0.0018 & 0.0023 & -0.0028 & -0.0025 \\
\hline & -0.12 & -0.19 & $3.97 * *$ & -0.53 & & -1.79 & 0.99 & -1.87 & -1.29 \\
\hline \multirow[t]{2}{*}{ Pspillover } & 0.0624 & 0.175 & 0.0182 & 0.0582 & Pspillover & 0.0183 & 0.208 & n.a. & 0.5558 \\
\hline & $6.59 * *$ & $6.27 * *$ & 1.84 & $3.33 * *$ & & 0.96 & $2.46^{*}$ & & 1.30 \\
\hline \multirow[t]{2}{*}{ Nspillover } & -0.0157 & -0.0778 & -0.051 & 0.2938 & Nspillover & 0.0227 & 0.0707 & n.a. & -0.1751 \\
\hline & -0.49 & -1.24 & -1.08 & $2.90 * *$ & & 1.83 & $3.28 * *$ & & -1.34 \\
\hline \multirow[t]{2}{*}{ Plagged } & -0.006 & -0.0525 & -0.0543 & -0.0481 & Nlagged & 0.0069 & 0.031 & n.a. & 0.0113 \\
\hline & -0.38 & -1.56 & -1.68 & -1.08 & & 0.71 & 0.35 & & 0.31 \\
\hline \multirow[t]{2}{*}{ Debt/GDP } & -0.0004 & -0.0005 & -0.0003 & 0.0001 & Debt/GDP & 0.0002 & 0.0006 & -0.0008 & 0.0019 \\
\hline & $-3.97 * *$ & $-2.32 *$ & $-1.99 *$ & 0.40 & & 0.62 & 1.28 & $-2.25^{*}$ & $2.97 * *$ \\
\hline \multirow[t]{2}{*}{ TA/GDP } & 0.1892 & 0.3674 & 0.2479 & -0.0679 & TA/GDP & -0.1639 & -0.1788 & -1.0366 & -0.2862 \\
\hline & 1.44 & 1.40 & 1.36 & -0.30 & & -0.49 & -0.27 & -1.79 & -0.76 \\
\hline \multirow[t]{2}{*}{ Constant } & 0.0236 & 0.0659 & -0.0708 & -0.0511 & Constant & 0.0344 & -0.0672 & 0.1485 & -0.1209 \\
\hline & 1.59 & $2.05 *$ & $-2.71 * *$ & -1.93 & & 1.24 & -1.37 & $2.74 * *$ & $-2.29 *$ \\
\hline Country dummies & Yes & Yes & Yes & Yes & Country dummies & Yes & Yes & Yes & Yes \\
\hline Year dummies & Yes & Yes & Yes & Yes & Year dummies & Yes & Yes & Yes & Yes \\
\hline $\mathrm{N}$ & 3077 & 1124 & 1069 & 884 & $\mathrm{~N}$ & 1077 & 551 & 211 & 382 \\
\hline $\mathrm{R}^{2}$ & 0.074 & 0.171 & 0.134 & 0.259 & $\mathrm{R}^{2}$ & 0.082 & 0.135 & 0.335 & 0.355 \\
\hline
\end{tabular}

This table presents the coefficient estimates of Eq. (4) using data samples of emerging market countries rated by S\&P, Moody’s and Fitch during January 2001 to September 2011. $C A R_{i j t}$ : the dependent variable, is the mean-adjusted cumulative abnormal return of bank $i$ in sovereign $j$ in the two-day event window $(0,+1)$ around sovereign rating actions at time $t$. Debt/GDP is the total government debt as a percentage of GDP of sovereign $j$ at the year-end prior to the sovereign rating action. TA/GDP is the total assets of bank $i$ over the GDP of its home sovereign $j$. All other variables are the same as specified in Table 4. We apply Huber-White robust standard errors, and t-statistics are reported beneath each coefficient. ** Significant at $1 \%$ level; * significant at $5 \%$ level. 


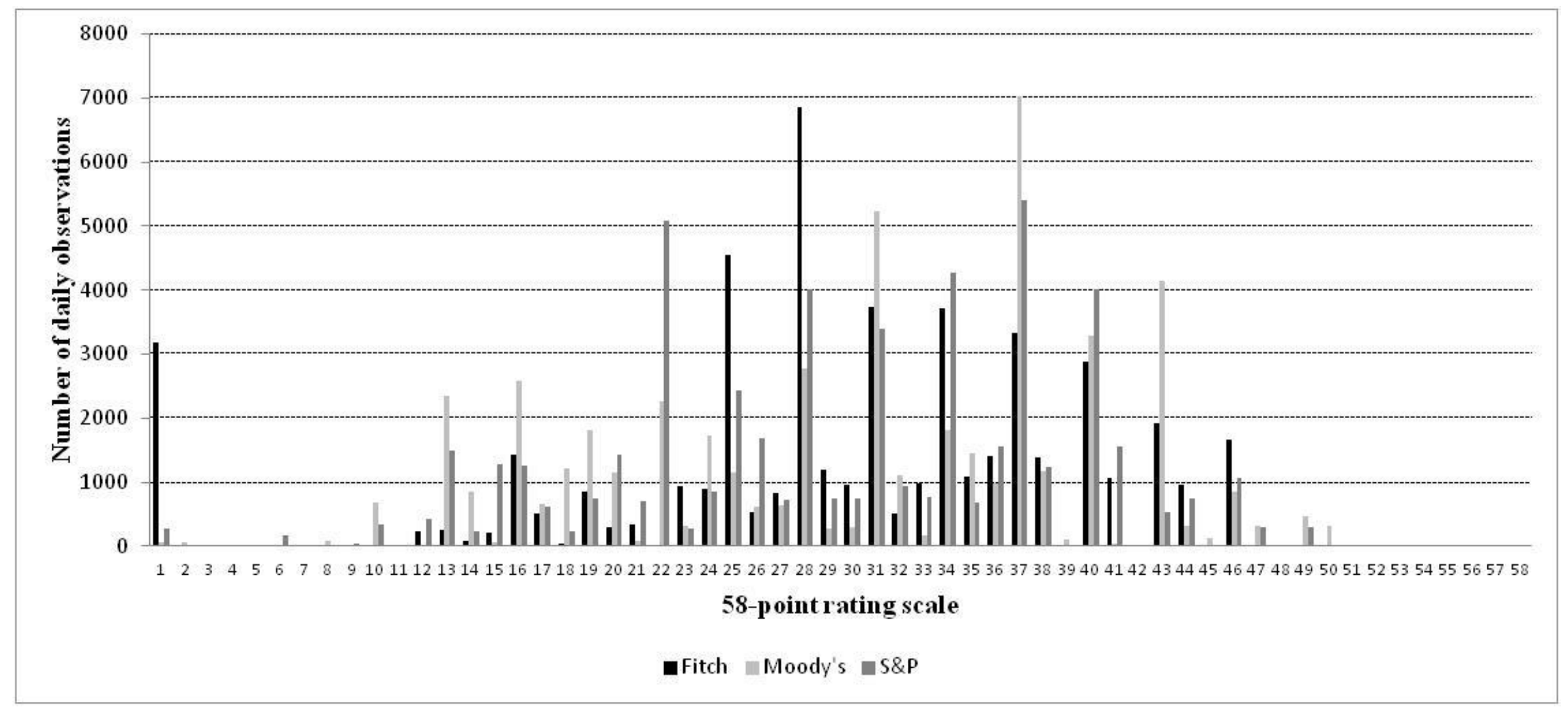

Fig. 1. Distribution of daily 58-point numerical ratings of 19 sovereign issuers in emerging markets during the period $1^{\text {st }}$ January 2001 to $30^{\text {th }}$ September 2011. See footnote 4 for the list of countries. The credit ratings scale is transformed into a 58-point numerical scale (See Table 1). 